\title{
Mathematical and Computational Models of Cell Cycle in Higher Eukaryotes
}

\author{
Alma Krivdic \\ Submitted to the \\ Institute of Graduate Studies and Research \\ in partial fulfillment of the requirements for the degree of \\ Master of Science \\ in \\ Applied Mathematics and Computer Science
}

Eastern Mediterranean University

September 2015

Gazimağusa, North Cyprus 
Approval of the Institute of Graduate Studies and Research

Prof. Dr. Serhan Çiftçioğlu Acting Director

I certify that this thesis satisfies the requirements as a thesis for the degree of Master of Science in Applied Mathematics and Computer Science

Prof. Dr. Nazim Mahmudov

Chair, Department of Mathematics

We certify that we have read this thesis and that in our opinion it is fully adequate in scope and quality as a thesis for the degree of Master of Science in Applied Mathematics and Computer Science.

Prof. Dr. Rza Bashirov

Supervisor

1. Prof. Dr. Rashad Aliyev

2. Prof. Dr. Rza Bashirov

3. Assoc. Prof. Dr. Benedek Nagy 


\begin{abstract}
The cell cycle is an ordered sequence of coordinated biological processes that enable cells to grow and divide, to check for certain abnormalities whenever it is appropriate, to regulate the different stages of growth and division in the predefined order, and to respond to DNA damage and other dysfunctions by arresting progression through the cell cycle so that to allow the regulators to repair DNA damage and recover from dysfunction before DNA is completely replicated. Understanding the detailed structure of cell cycle regulation is of practical importance in biotechnology, medicine, and pharmacology. Since a detailed analysis of cellular mechanisms behind of cell cycle regulation is too complex to be preformed intuitively, mathematical and computational modeling of involved processes is essential part of the research in this field. The main idea behind this approach is to create the closest approximation of a biological system based on wet lab results, and predict its dynamic behavior through measuring the amounts of biological components. Mathematical and computational approaches implemented to cell cycle regulation have the following benefits. Firstly, it makes possible to provide a detailed qualitative and quantitative structure of the biological system describing the cell cycle regulation. Secondly, modeling allows us to conjecture a hypothesis regarding the biological system and then check consistency of the hypothesis to desired deep by extrapolating the parameters involved into the model.
\end{abstract}

Keywords: cell cycle, mathematical model, computational model, Petri nets 


\section{ÖZ}

Canlı hücrelerin büyümesi, bölünmesi, hücre içi belirli anormalliklerin aşamalı kontrolü, DNA hasarı, DNA hasarının giderilmesi gibi ardışık süreçler dizisine hücre döngüsü denir. Hücre döngüsünün detaylı yapısal düzenini anlamak biyoteknoloji, tıp ve farmakolojideki uygulamalar açısından pratik önem arz etmektedir. Hücre döngüsünü oluşturan moleküler mekanizmalar çok karmaşık olmanın yanı sıra sezgisel olarak incelenmeleri olanaksız görünmektedir. Bu bakımdan matematiksel ve bilgisayar ortamında oluşturulan modeller hücre döngüsü ve bileşenlerini anlamak için bu alan kullanılan önemli araştırma yöntemidir.Matematiksel ve bilgisayar ortamında sayısal simülasyon biyolojik sistemleri keşfetmek için uygulanan verimli bir yaklaşımdır. $\mathrm{Bu}$ yaklaşımın ana fikiri laboratuvar sonuçlarına göre biyolojik sistemin olabilecek kadar gerçekçi modelinin oluşturulması ve biyolojik bileşenlerin miktarlarını ölçerek dinamik davranışların tahmin etmektir. Hücre döngüsünün düzenlenmesi için uygulanan matematiksel ve sayısalın modeller ilk önce hücre döngüsünün olabilecek kadar detaylı nicel ve nitel yapısını oluşturma, hücre içi molekuler süreçleri anlama, varsayımlar veya hipotezler öne sürme, ve bu varsayım veya hipotezlerin tutarlılığını kontrol etmenizi sağlar.

Anahtar Kelimeler: Hücre döngüsü, matematiksel model, hesaplama modeli, Petri ağları 


\section{DEDICATION}

I would like to dedicate this thesis to my fellow countrymen and countrywomen called Bosnians and Herzegovinians including my family, and all my former and current teachers. 


\section{ACKNOWLEDGMENT}

First of all I would like to thank my family for enormous support they have given me in my entire academic life. Without their belief that science can change lives and without their recognition of my abilities and talents, I would not be so patient and persistent in endeavors I have persuaded.

Every long - term project, how I call anything planned, requires effort of all people included. Without proper guidance student cannot learn and apply knowledge. I would like to thank my supervisor Prof. Rza Bashirov for leading my research in a right way. He had been true mentor and advisor in last one year, as well as previously during my undergraduate studies. I would like to thank him for opening new horizons of modern science for me (biogenetical research and its applications).

Also, I would like to thank Prof. Yucel Tandogdu for encouraging me to return to EMU for Master degree and for moral support in this endeavor.

I would like to thank my classmates and friends and especially Yves Yannick for numerous studying and coffee times we have spent together. 


\section{TABLE OF CONTENTS}

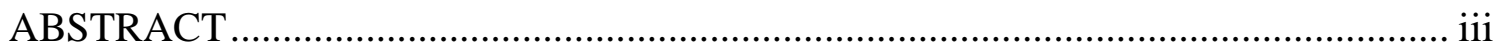

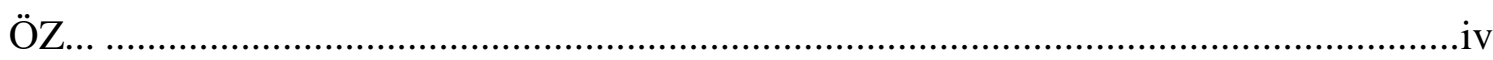

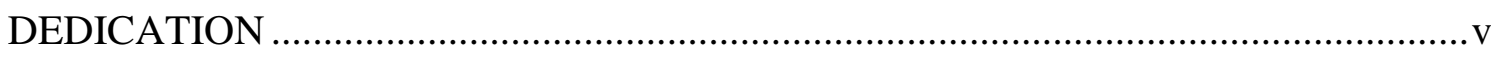

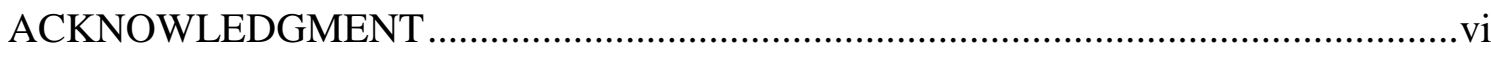

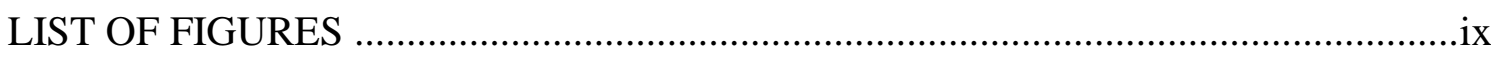

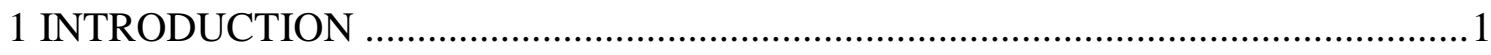

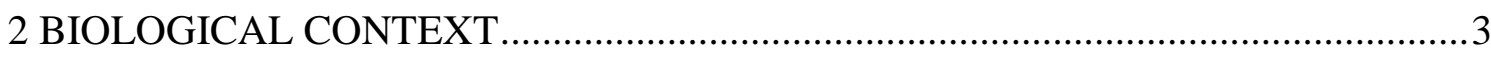

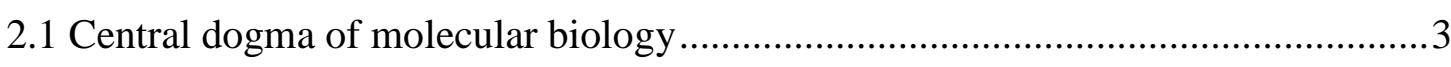

2.2 Metabolic, signal transduction, and gene regulatory pathways............................15

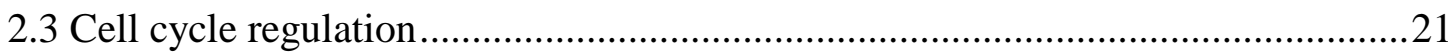

3 MATHEMATICAL AND COMPUTATIONAL MODELING ...............................23

3.1 Intoduction (quantitative, qualitative, and stochastic approach) ........................23

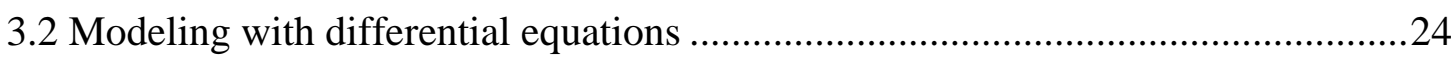

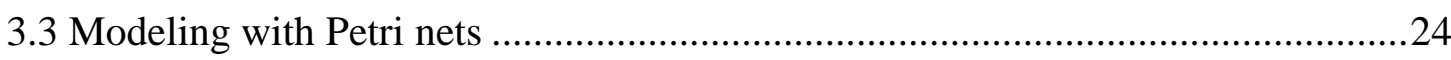

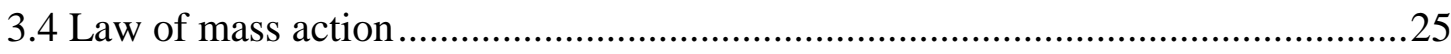

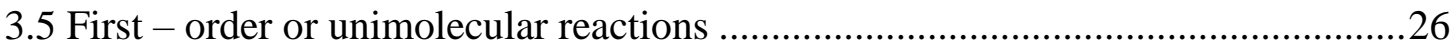

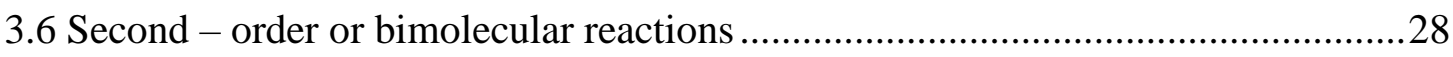

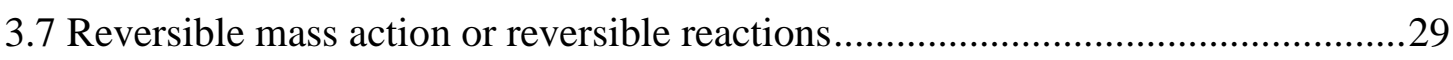

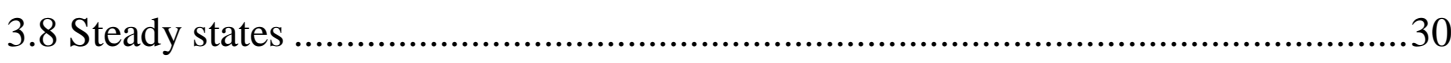

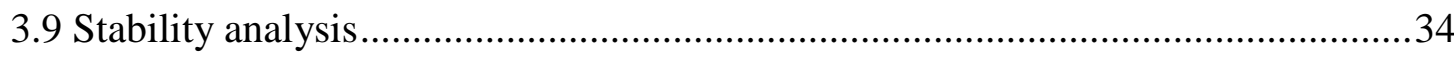

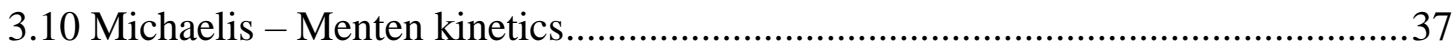

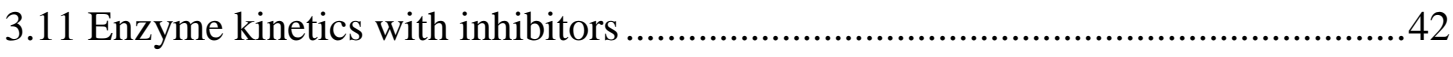

vii 
3.11.1 Enzyme kinetics with compatative inhibition 42

3.11.2 Enzyme kinetics with uncompatative inhibition ..................................44

3.11.3 Enzyme kinetics with noncompatative inhibition ...................................45

4 CONCLUSION

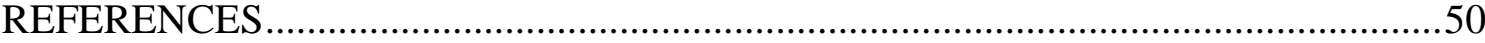




\section{LIST OF FIGURES}

Figure 1. Information from genes is used to make proteins ........................................

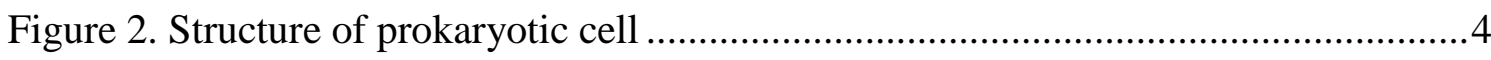

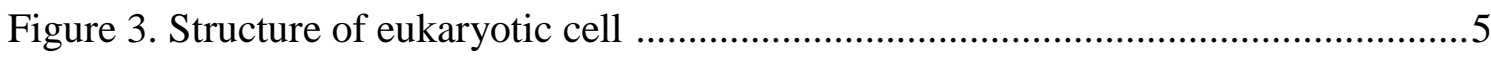

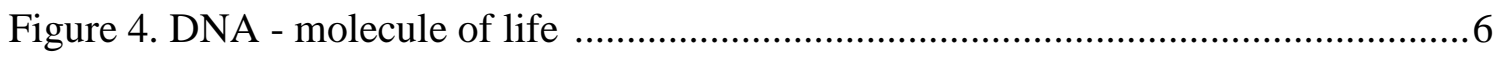

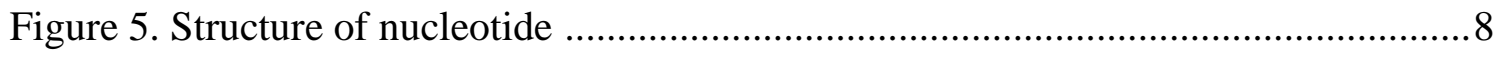

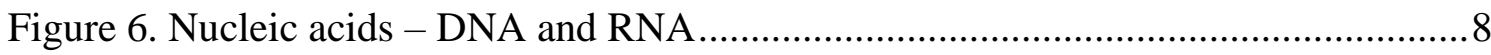

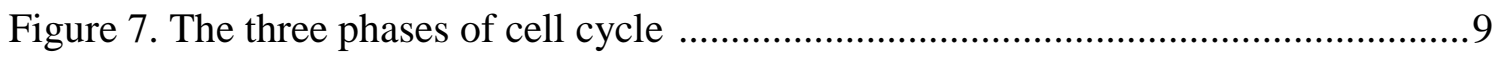

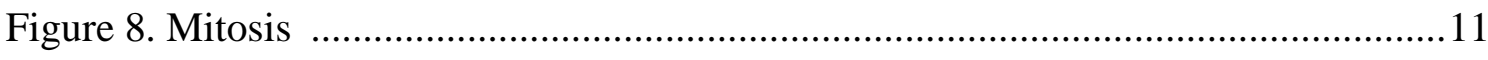

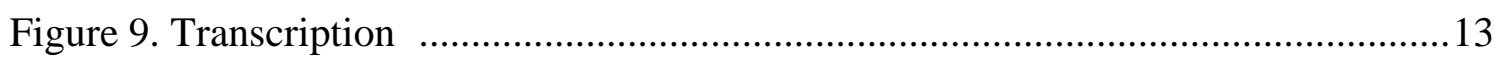

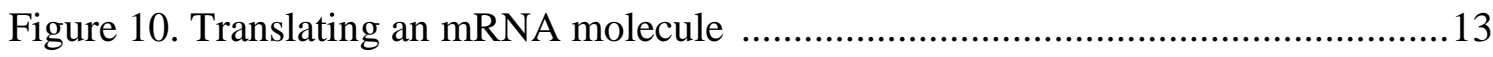

Figure 11. A simple intracellular signaling pathway ............................................... 17

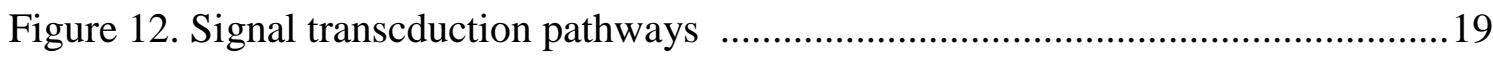

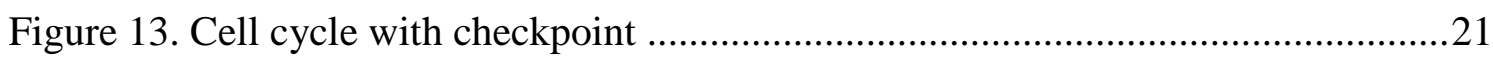

Figure 14. Systems biology - modeling as formal knowledge representation ...............23

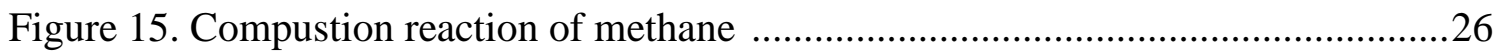

Figure 16. Petri net representation of unimolecular reaction …..................................27

Figure 17. Petri net model of bimolecular reaction .............................................. 28

Figure 18. Petri net model of reversible unimolecular reaction ...................................29

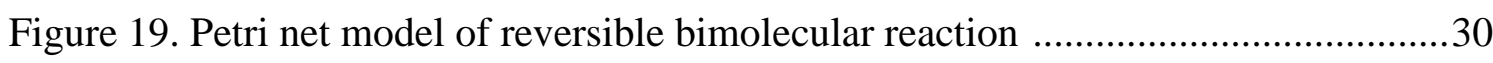

Figure 20. Sketch of a limit cycle in the phase plane of concentrations ..........................36

Figure 21. Petri net model of enzymatic reaction .................................................... 38

Figure 22. Saturation curve for enzyme reaction ..................................................41 
Figure 23. Basic working process of enzyme .42

Figure 24. Petri net representation for competitive inhibition ...................................43

Figure 25. Petri net representation for uncompetitive inhibition ...................................44

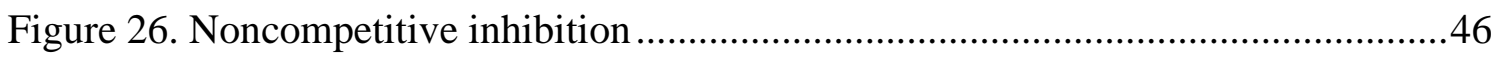

Figure 27. Petri net representation for noncompetitive inhibition ...............................46 


\section{Chapter 1}

\section{INTRODUCTION}

We will first explain why we have chosen this topic as our research objective. In last 50 years science and technology has advanced with exponential rate. It has become difficult to choose right topic for research that has not been researched already to certain extent. However, bioinformatics is one of newer fields of computer science. It depends on developments in both biological (including genetics) engineering and computer science. Base for any kind of computational models are mathematical principles of course. Among topics in biogenetics we have chosen to pick one that has immediate and significant impact in real life. Modeling cell cycle can help in couple of things: from understanding dynamics of metabolism and duplication of cells, enhancing those processes to defining cures for diseases that are caused by irregularities in cell cycle (one of the best examples would be cancer).

Reason why mathematics and computer science came into picture of modeling cell cycle is that we are still not able to properly examine and follow with electronic microscopes all what happens within cell. We need to use data available and make assumptions in order to get approximate results for experiments performed. There into picture comes computer science that has managed, until now, to successfully model dynamics of many live and artificial systems. 
In order to analyze cell cycle we need to make proper model. First instance in making model is qualitative analysis that will enable us to define structure of biological process we are concerned with. After defining structure of process, we will be concerned with dynamics of process. To explain dynamics we need to make quantitative model. After obtaining structure with dynamics, we will try to predict outcomes of different scenarios that might happen within process. For that we will need to shape stochastic model.

Mathematical tool we will use are differential equations. They are handy tool for describing dynamics of real time processes. Computational tool that we have chosen are Petri nets as they can model discrete, continuous, hybrid, and stochastic environments.

This thesis is organized in the following way: first we will give insight into biological context explaining structure of cell, cell division process, cell cycle process, and regulation of cell cycle. Second part of thesis describes mathematical and computational models used for modeling processes explained above.

In our research we focused on processes in higher eukaryotic cells as human organisms are built from same one. 


\section{Chapter 2}

\section{BIOLOGICAL CONTEXT}

\subsection{Central dogma of molecular biology}

Central dogma of biology describes synthesis of proteins within cell. It states that deoxyribonucleic acid (DNA) is transcripted into messenger RNA (mRNA) inside of nucleus. Following that process, mRNA is translated into protein. Sketch is given below.

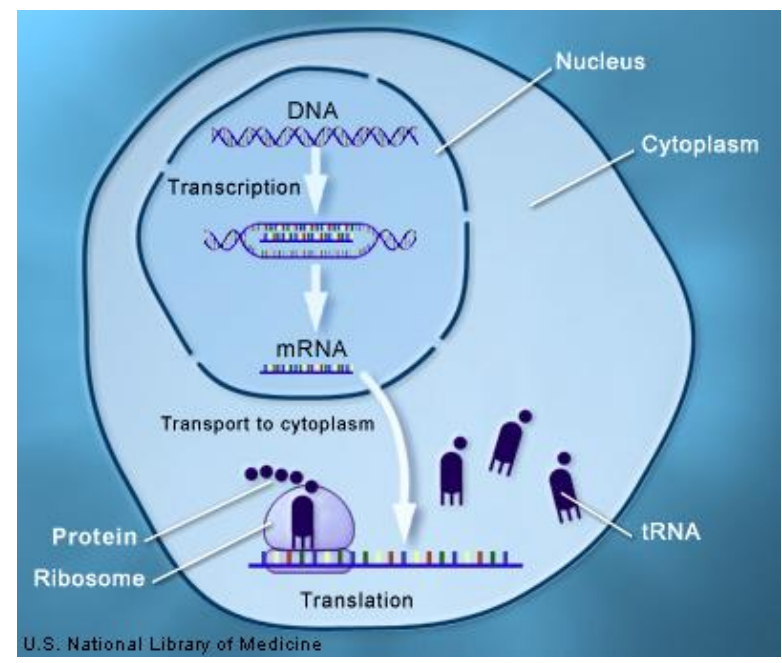

Figure 1. Information from genes is used to make proteins (taken from [1])

Protein synthesis is extremely important process within cells, without which living would be impossible. Proteins have variety of roles as: giving rigidity to the framework of an organism (collagen), providing flexibility of organism (motor 
proteins), catalyzing cellular reactions (enzymes), and controlling cellular activities as regulators (hormones like insulin).

To understand transcription and translation from DNA thru mRNA into protein, firstly we need to explain what cell cycle is. Cell cycle is the critical process of duplication and division of genetic information. Genetic information is stored within cell and it will be in detail described afterwards. To continue with giving insight what central dogma of molecular biology is, we need to define cell structure, cell cycle and its phases, and processes within.

Structure of Cell

Cell is made of cell wall and membrane, ribosomes, and cytoplasm.

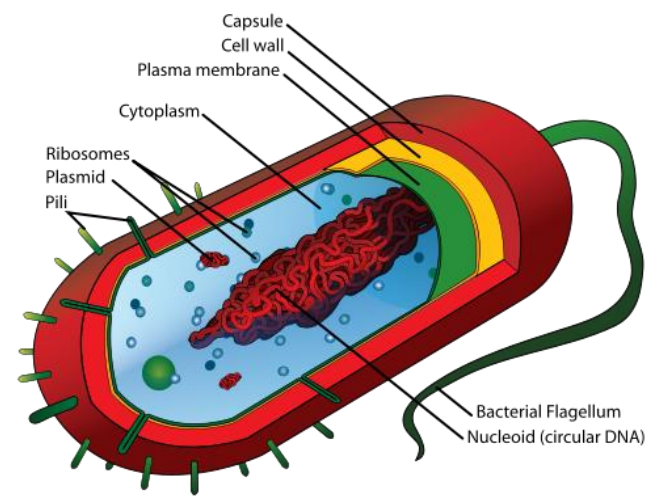

Figure 2. Structure of prokaryotic cell (taken from [2])

There are two types of cells: prokaryotic and eukaryotic. Prokaryotic cell does not have nucleus and organelles. Its cytoplasm has nucleotide with one chromosome. Organisms made of prokaryotic cells include two distinct groups: the bacteria and the archaea. Prokaryotic organisms are unicellular although some species form colonies. 


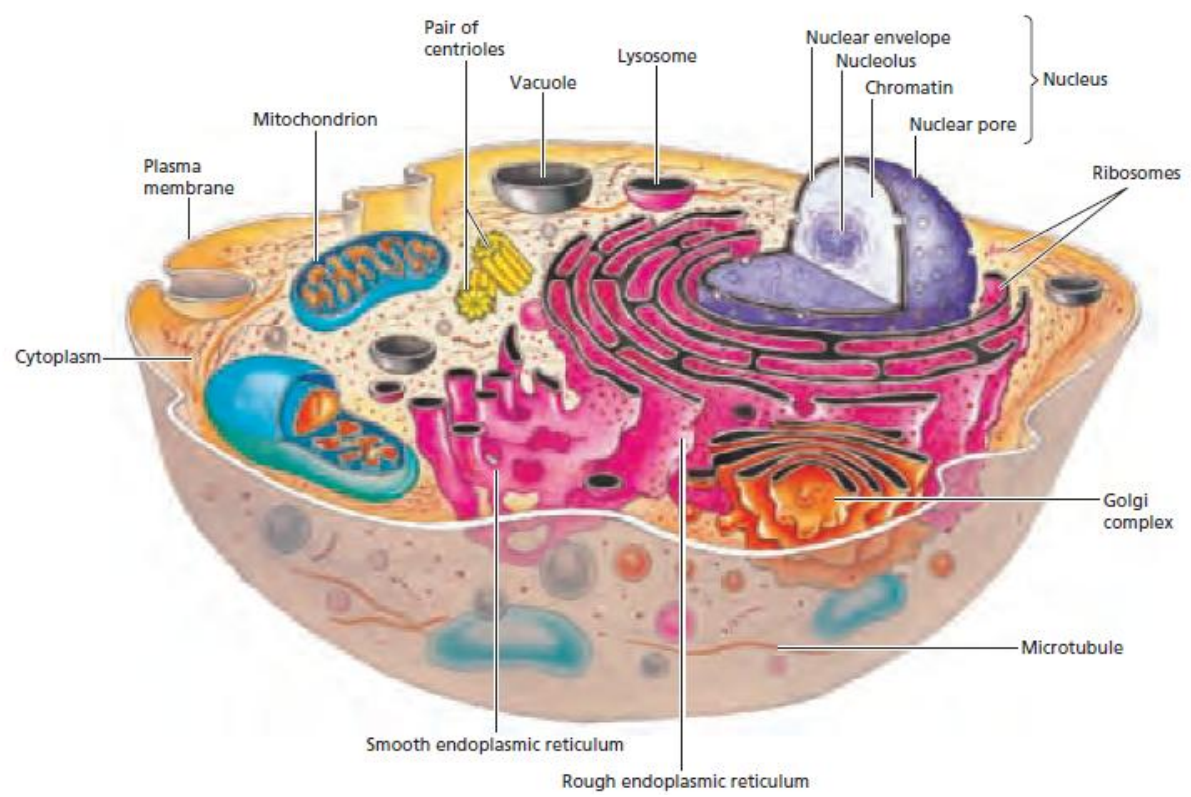

Figure 3. Structure of eukaryotic cell (taken from [3])

Eukaryotic cell has membrane-surrounded organelles within cytoplasm and membrane enclosed nucleus that contains genetic information. Organelles in a typical eukaryotic cell are: mitochondria, the endoplasmatic reticulum, the Golgi complex (apparatus), lysosomes, and peroxisomes as shown in the figure above. The nucleus is also referred as organelle. Eukaryotic organisms can be either unicellular or multicellular. Eukaryotes comprise all the macroscopic forms of life: plants, animals, fungi, and human. In our work we will mainly consider processes in eukaryotic cells of Schizosaccharomyces pombe (fission yeast), Saccharomyces cerevisiae (budding yeast), zerra fish, rat, and so on. It is important to mention that proteins involved in cell cycle are the same in both human and yeast cells. That is reason why we examine yeast cells when we want to find solution for human diseases. It has been shown that proteins from different organisms can be functionally interchangeable. 
After describing structure of both prokaryotic and eukaryotic cell, we are going to explain what is genetic material, how it is replicated and passed from cell to its daughter cells as well as how protein synthesis is carried out.

Genetic material is stored in genome. Genome is collection of all genes in cell. Genes are parts of DNA (deoxyribonucleic acid) molecules. Gene is unit of inheritance and the genome is all of those units added together.

DNA and RNA are the polymer molecules made up of subunits monomers. Those subunits are called nucleotides. Nucleotides form polynucleotide that can have millions of nucleotides in its chain.

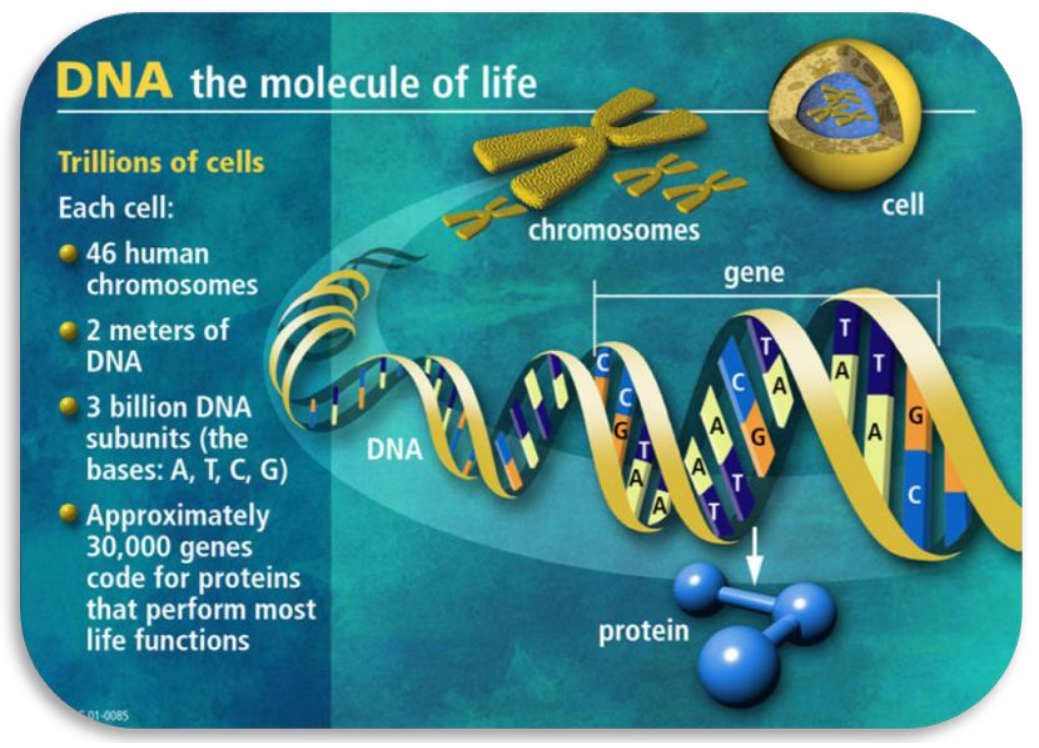

Figure 4. DNA - molecule of life (taken from [4])

Physically, DNA molecule is packaged into thread-like structures called chromosomes. Chromosomes are made of both DNA and another kind of proteins 
called histones that support structure of chromosome. Histones make up chromatin together with DNA plus RNA. Chromatin is complex of macromolecules and its structure depends on phase of cell cycle. For example, during interphase it becomes loose enabling DNA to replicate. So, chromosomes make up chromatin and they are only visible during division phase.

Eukaryotic genomes are made of linear DNA molecules, each of these molecules contained in a different chromosome. The number of chromosomes varies between species, and appears to be unrelated to the biological features of the organism.

Now to get back to structure of DNA and RNA, involved in transcription and translation, we need to describe nucleotides. Nucleotides are molecules made of nitrogen-containing ring compound linked to a five-carbon sugar, which can be either ribose or deoxyribose having attached one or more phosphate groups. Phosphate groups are hydrophilic meaning that they will react with water easily. This characteristic enables phosphorylation and dephosphorylation that will be important in modeling cell cycle processes. 


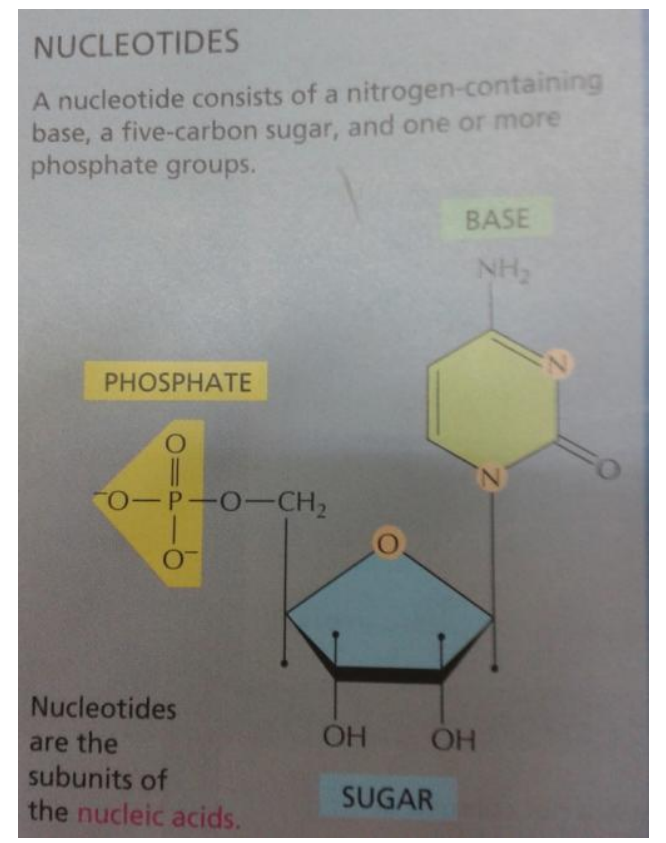

Figure 5. Structure of nucleotide (taken from [5])

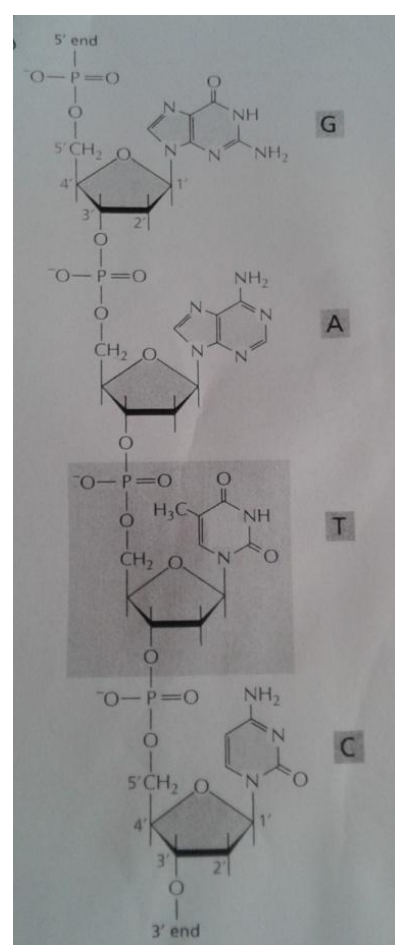

Figure 6. Nucleic acids - DNA and RNA

All cells contain DNA as a store of genetic information and use it to guide the synthesis of RNA molecules and proteins. 


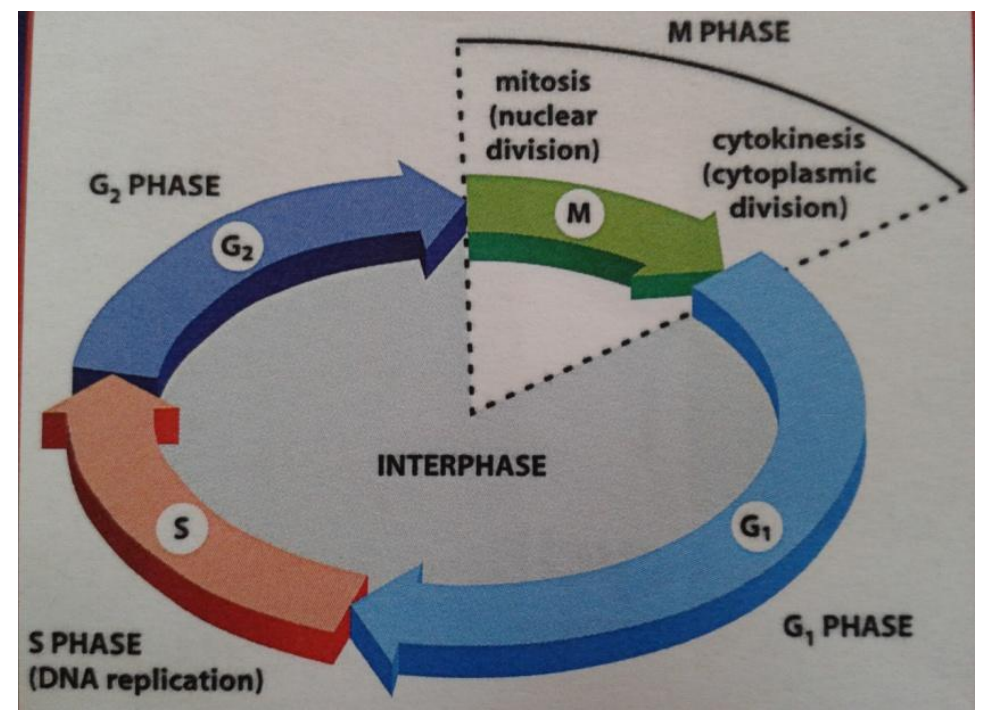

Figure 7. The three phases of cell cycle (taken from [5])

Cell cycle is made of three phases: interphase, mitosis (M), and cytokinesis. Figure above is depicting all the phases including three stages of interphase.

Interphase is period of cell growth and genetic material duplication. It is also referred as period between two cell divisions. Mitosis is process of division of chromosomes and cytokinesis is division of cytoplasm.

When cell finishes division it is called daughter cell and it is one half size of its parental cell. For daughter cell to duplicate, it has to grow to size of its parental cell. So, first phase of cell cycle is growth period of organelles, membranes, and ribosomes. It is called G1 (gap1) phase of the interphase. After G1 phase if cell passes first G1/S checkpoint, it will be explained later, it starts with DNA replication meaning chromosomes form sister chromatids. That is S or "synthesis" phase. G2 
(gap2) phase marks preparation of cell for division. Cell in G2 phase is tetraploid contains two DNA molecules. There is checkpoint between G2/M phases where checking of successful chromosomes duplication and DNA damage is carried out. In case that DNA is damaged, cell will not pass thru G2/M checkpoint towards mitosis phase meaning cell division will be stopped. In eukaryotic cell proteins that coordinate, control, and regulate cell cycle including G1/S and G2/M checkpoints are called cyclins and cyclin-dependent kinases (CDKs). However, they do not exist in prokaryotic cell. Cyclins and cyclin-dependent kinases act in pairs, as it will be shown afterwards in this work, and that pairing is similar for all eukaryotic organisms from yeast cells to mammals.

If chromosomes have replicated successfully and DNA is undamaged, cell will enter mitosis. Mitosis has four phases as shown in diagram below: 

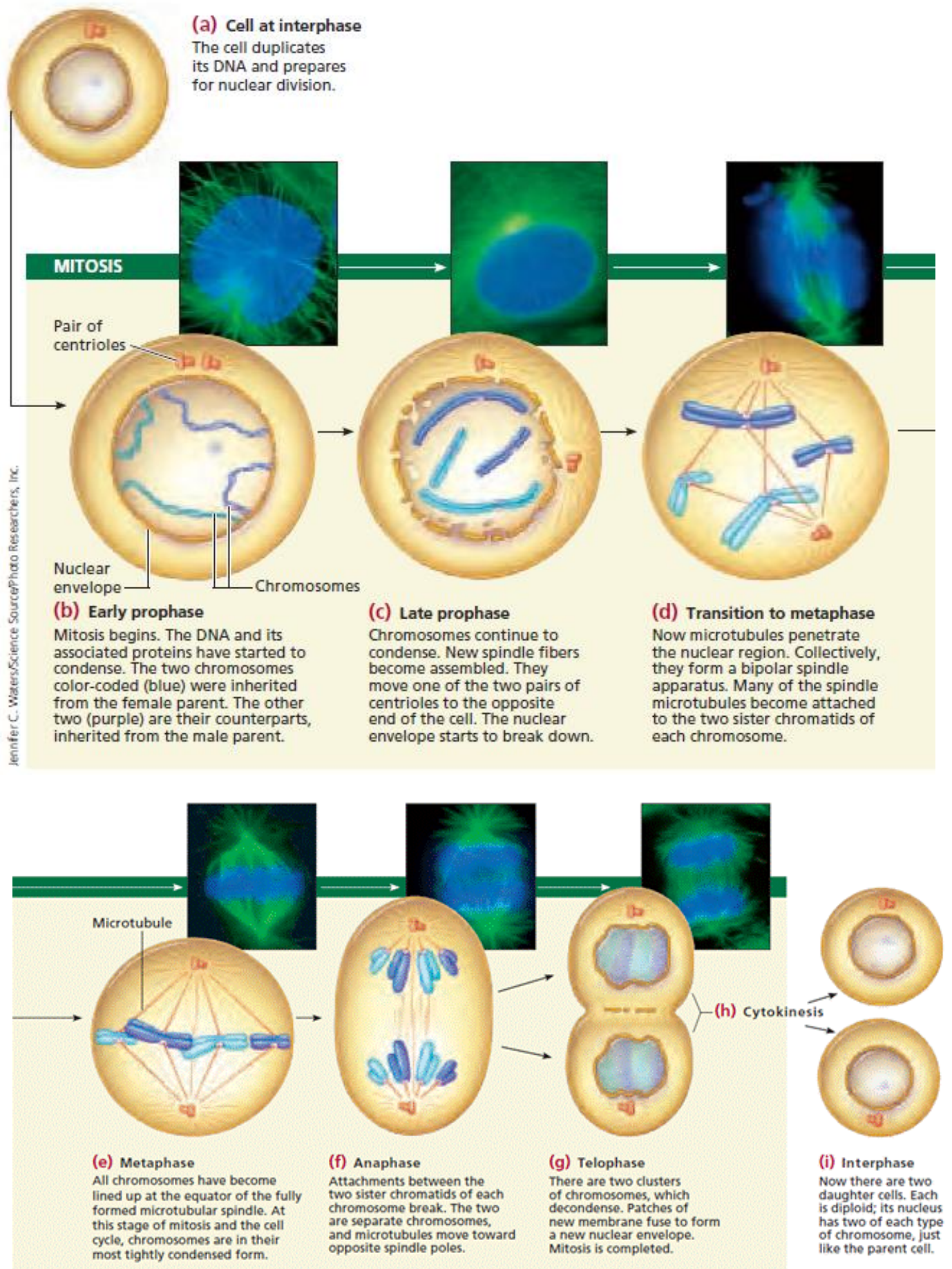

Figure 8. Mitosis - Only two pairs of chromosomes from a diploid ( $2 n)$ cell are shown here. The photograph show mitosis in a mouse cell; the DNA is stained blue and the microtubules of the spindle fibers are stained green. (taken from [3]) 


\section{Protein synthesis}

After describing cell cycle process we will return to protein synthesis. To synthesize protein RNA has to be generated from DNA and that information decoded for peptide, protein, creation. DNA is double stranded and RNA is single stranded. Transcription is process in which RNA is generated from DNA. Translation is process of creating proteins from mRNA. This mechanism by which proteins in cell are produced from DNA is also known as "gene expression". Gene expression is important because all processes in cell are performed by proteins. The linear sequence of nucleotides in a DNA or a RNA molecule encodes biological information. As we have seen before, DNA is double-bounded helices and it acts as long-term repository for hereditary information, while single-stranded RNA is usually transient carrier of molecular instruction. The bases in different nucleic acids molecules pair (and recognize) each other by hydrogen-bonding called base-pairing; ex: adenine A with either thymine T or uracil U. Base-pairing underlines all of the heredity and evolution.

Translation and transcription are, in principle, same for bacteria and eukaryotic organism. However, they are more complex for eukaryotic organisms because they need more enzymes to be carried on (translation). Copying DNA into RNA is performed adding nucleotides, one at the time, of DNA-dependent RNA polymerase enzyme to growing mRNA. This RNA polymerase enzyme is extremely important for gene expression and has been found in cells of all types of organisms including viruses. Transcription in eukaryotic cell engages three types of RNA polymerase enzyme called RNA polymerase I, RNA polymerase II, and RNA polymerase III. 


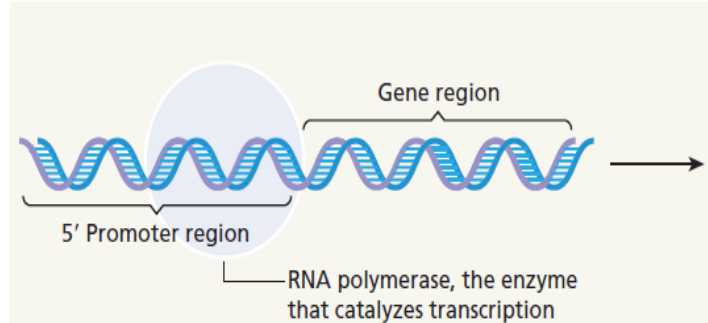

(a) RNA polymerase binds to a promoter in the DNA, along with regulatory proteins (initiation). The binding positions the polymerase near a gene in the DNA.

Only one strand of DNA provides a template for transcription of mRNA.

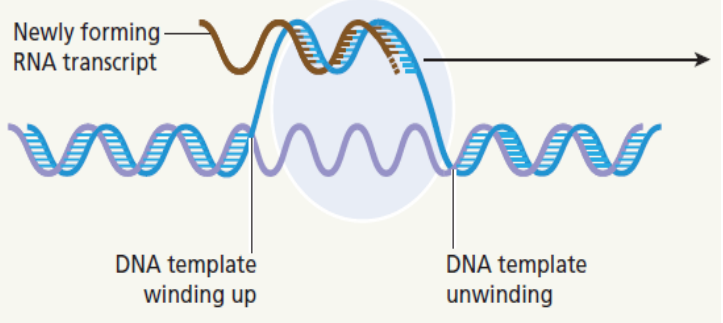

(b) The polymerase begins to move along the DNA and unwind it. As it does, it links RNA nucleotides into a strand of RNA in the order specified by the base sequence of the DNA (elongation).

The DNA double helix rewinds after the polymerase passes. The structure of the "opened" DNA molecule at the transcription site is called a transcription bubble, after its appearance.

Figure 9. Transcription (taken from [5])

Apart from RNA polymerase, eukaryotes have more transcription factors that also control transcription process. Sometimes all of them are called transcription initiation complex. After it was created in nucleus, mRNA usually exits nucleus and enters cytoplasm to continue with process of translation. This is case for eukaryotic cells. However, for prokaryotic cells this translation process happen while RNA is still being created, during transcription.
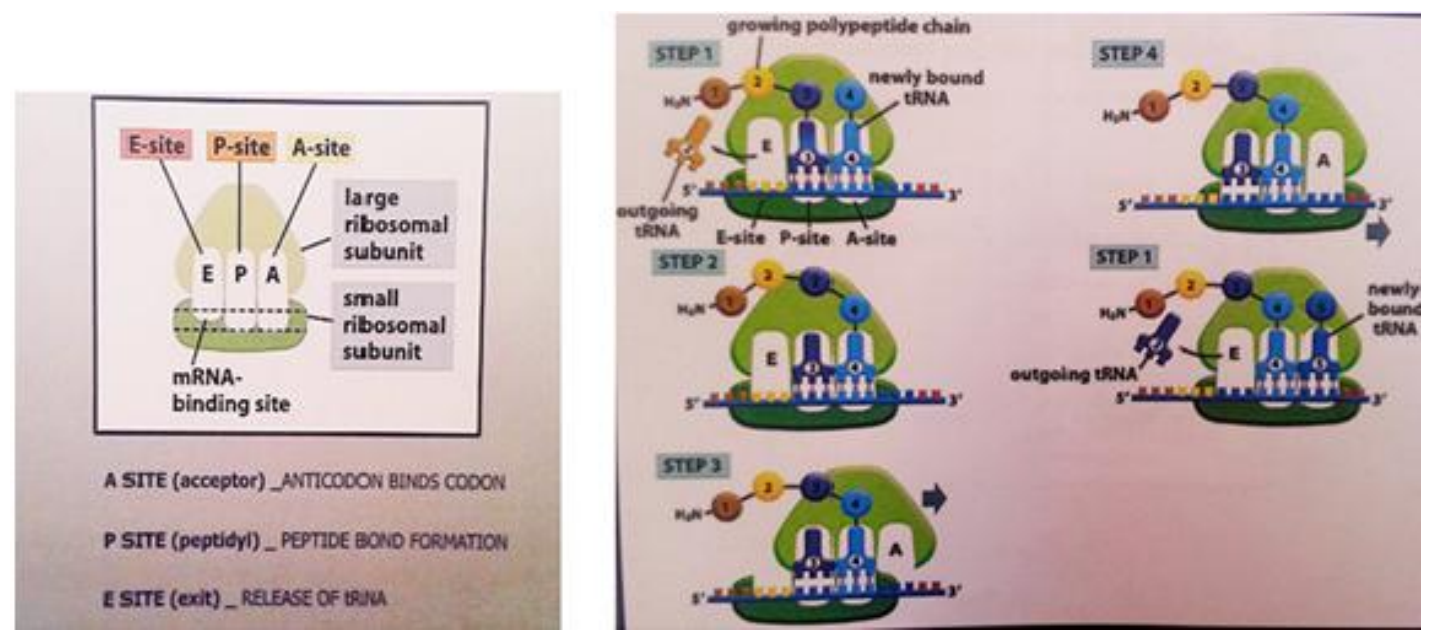

Figure 10. Translating an mRNA molecule (taken from [5]) 
In cytoplasm mRNA (in figure above $5^{\prime} \rightarrow 3^{\prime}$ strand) interacts with organelle called a ribosome. Ribosome has large and small ribosomal units, as shown in figure above. Transfer RNA (tRNA) brings amino acids to the mRNA complex in order specified by mRNA. Usually, sequence within mRNA of three bases called codon codes for one amino acid that are building blocks of proteins. tRNA is organized into anticodons that pair with codons of mRNA in complementary order. Pairing is stopped when ribosome encounters a "stop" codon (a sequence of three bases that does not code for amino acid). Assembling amino acids into polypeptide chains is than done by enzyme called ribosomal RNA (rRNA). To form protein tRNA needs to link together amino acids into protein chain, one by one at the time.

For protein synthesis to start, corresponding genes needs to turn on. Although some "housekeeping" genes are always turned on, most of genes are turned on and off depending on organism's needs. Process of turning genes on and off is called gene regulation. Now we came to the point how different cells perform different tasks and make up different tissues and organs. Turning on certain genes during development will make cell to be brain cell or heart cell or skin cell. Also, gene regulation is mechanism that allows cell to react quickly to environmental changes. Gene regulation usually occurs during transcription phase of gene expression but it can happen at any point in mentioned process. Gene regulation is regulated by so-called genetic regulatory networks that will be described in detailed in the next session of this thesis. 


\subsection{Metabolic, signal transduction and gene regulatory pathways}

Gene regulation and cell cycle actually represent network of biochemical reactions within cell itself and in some cases between cells as well. All processes in cell form huge network but there are three main layers: metabolism, signal transductions, and gene regulations. Every layer has defined network of pathways so in the following text we will describe what are metabolic pathways, signal transduction pathways, and gene regulatory pathways.

\section{Metabolism and metabolic pathways}

Metabolism represents production and degradation of diverse small molecules (metabolites) needed for an organism to function properly. Metabolites are important for growth, development, and reproduction of living organism. Primary metabolites area amino acids, sugars like glucose and fructose. Secondary metabolites, that have less vital functions, are antibiotics, pigments, and hormones.

\section{Degradation or breakage of organic compounds is called catabolism. By} catabolic reactions cell receives energy needed to perform all processes. Energy produced is in the form of nucleotides called adenosine triphosphate (ATP), it contains three phosphates.

Metabolic reactions are enzymatic reactions meaning that there is initial compound called substrate upon which protein, called enzyme, acts in order to form new compound called product. Metabolic reactions are usually not as fast as needed for 
cell to live properly, so there is need for catalysts that would speed up those reactions. Those catalysts are called enzymes and they speed up metabolic reaction with significant rate. Enzymes also define which metabolic reactions will occur in a cell. It is quite regular that same chemical reaction is catalyzed by different enzymes. But this is also true that different enzymes have different amino acid sequence and so they are called isozymes or isoenzymes. Enzymes increase speed of reactions but there are molecules that decrease activity of enzymes. They are called inhibitors. Reaction with inhibitors can be reversible or irreversible. Reversible inhibition has the same enzyme activity in the beginning and at the end of the reaction. Apart from this classification, inhibition can also be: competitive, noncompetitive, and uncompetitive. Those types of reactions will be in detail explained in Section $3.11-$ Enzyme kinetics with inhibitors.

Usually product of one enzymatic reaction acts as substrate for next one. To give an example, ATP produced by catabolism is further used for synthesis of DNA and RNA, and transcription and translation processes. Apart from metabolic processes, ATP is widely used also for signal transduction and gene regulation processes. Some of examples have been just mentioned above.

We have just described catabolism. Opposite to catabolism is anabolism in what new compounds are built from the basic units. Anabolism requires energy either from catabolism or from outside of cell. For organism to maintain so-called homeostasis (a process ensuring the stability of the human body's internal environment in response to changes in external conditions) it requires metabolic pathways to function 
properly. Some metabolic pathways are similar in all organisms while some are different. Usually they are linear, producing specific products from substrates but they might generate intermediate metabolites by which they are connected to other pathways. All metabolic pathways are connected into metabolic network that is quite dense.

\section{Signal transduction pathways}

Our research has been targeting eukaryotic cells that are basic unit of multicellular organisms. As we mentioned earlier, one of the most important functions that organism has to maintain is so-called homeostasis, balance and stability of the body. It does so thru system of signaling networks within each cell, that reacts to the changes outside of organism, inside itself (cell), and also in surrounding cells. Communication between cells and within cell itself represents series of chemical reactions called signal transduction pathways.

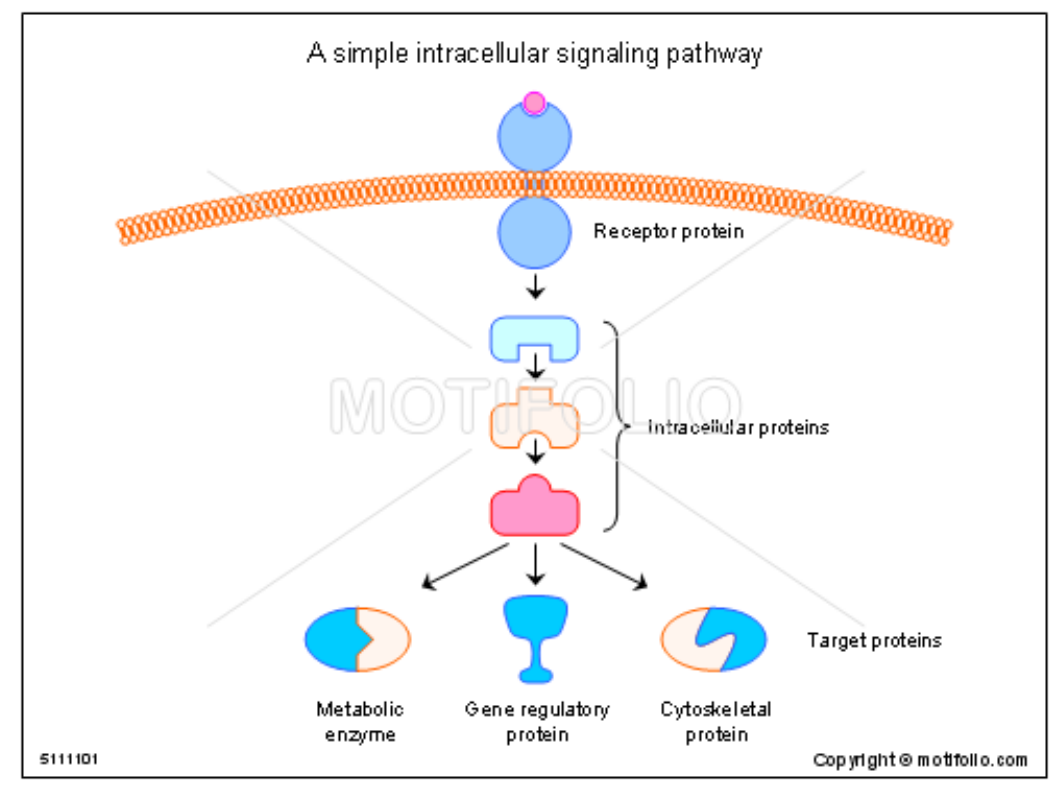

Figure 11. A simple intracellular signaling pathway 
As we can see from figure above, extracellular signaling molecule hands over the start signal, stimulus, to a specific receptor protein that is either on the cell surface or inside the cell. Stimulus passed to the receptor is further passed from receptor to intracellular proteins called messengers. Messengers amplify the signal and pass it over to effector molecules. Result is response of the cell to the start signal and it can be cell proliferation, cell death, cell differentiation, changes in cell metabolism, and gene expression. Signals can be response to environmental changes such as light and pressure or to internal changes within organism such as hormone concentration or growth factor concentration.

One signaling molecule can cause many reactions and that is called signaltransduction cascade. Usually, after series of response reactions signal transduction activates gene expression. As stated by Kohn and all (2011), "The term signal transduction network refers to a complex of all reactions (including interactions) in signaling from receptors to final targets that mediate the specific gene expression". We have seen before that most of the metabolic pathways include enzymatic reactions. Same goes for signal transduction pathways and networks. 


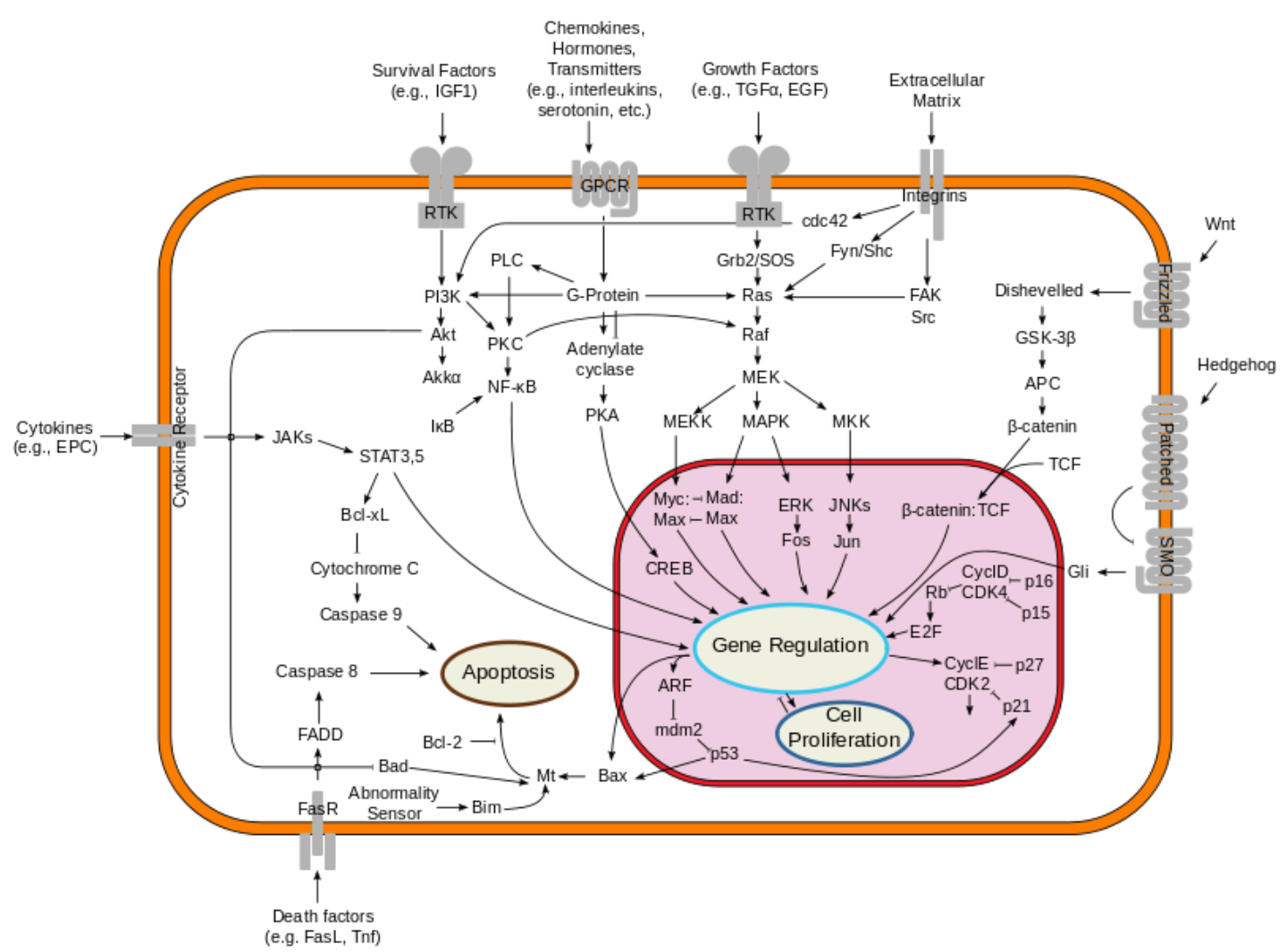

Figure 12. Signal transcduction pathways (taken from [6])

Now it is the moment to define certain kind of proteins that act as enzymes in many of those reactions called kinase.

\section{Kinase}

A kinase is a type of enzyme that catalyzes the transfer of phosphate groups from high-energy, phosphate-donating molecules to specific substrate. This process is called phosphorylation. Example of phosphorylation is when high-energy adenosine thriphosphate (ATP) donates a phosphate group to substrate producing a phosphorylated substrate and adenosine diphosphate (ADP). 
Dephosphorylation is reverse process where kinase takes a phosphate group from a phosphorylated substrate causing ADP to gain a phosphate group producing in this way a dephosphorylated substrate and the ATP.

In our work we will be concerned with protein kinases that are involved in signaling pathways regarding transcription and translation processes as well as regulation in cell cycle.

\section{MAPK pathway}

One of the most researched pathways is called MAPK pathway what stand as abbreviation for the mitogen activated protein kinase signaling pathway. MAPK mitogen activated protein kinase is protein enzyme that leads to mitosis. Mitogen is protein that encourages cell division by triggering above mentioned kinase. MAPK pathway takes part in regulation of many genes and is essential to development of several cellular processes. The MAPK can be thought of as a cascade of kinases where each kinase phosphorylates the next one in order to deliver signal so that the last kinase phosphorylates the target protein.

\section{Gene regulatory pathways}

Gene expression is regulated by gene regulation mechanisms as we mentioned earlier. Gene regulation can occur at any point during gene expression, but most commonly it occurs at the level of transcription when DNA is transcripted into mRNA. Gene regulation is performed thru network of genetic regulatory pathways. Apart from that, genetic regulatory networks regulate interactions between genes. Gene regulatory pathways act in specific amounts and in specific time and place. 
Gene regulatory network consist of a signaling pathway, a target genes, and gene products. There are two types of genetic regulatory networks:

- Transcription factor network

- Gene expression network

\subsection{Cell cycle regulation}

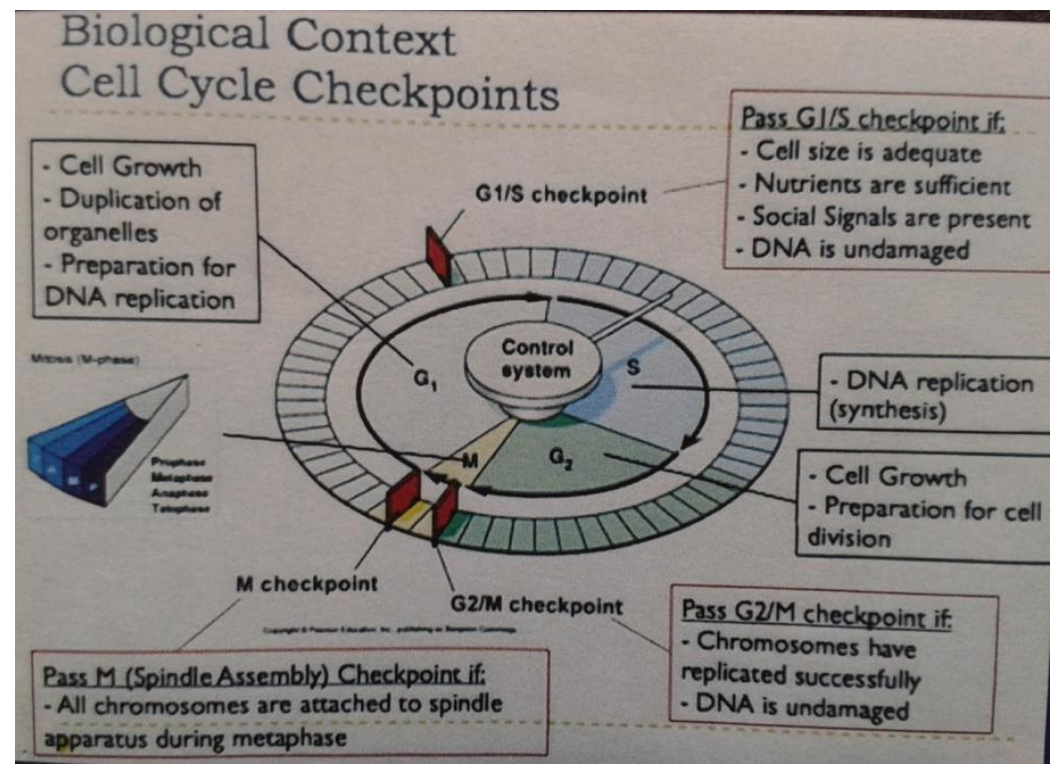

Figure 13. Cell cycle with checkpoint

There are couple of checkpoint during cell cycle. They enable or disable further stages of cycle to begin and continue. First checkpoint is between phases G1 and S where checking mechanism inspects if cell size is adequate and among other things if DNA is undamaged or not.

Second checkpoint is after phase G2 where mechanism checks if chromosomes have been replicated properly and again if DNA is undamaged or not. 
There is also checkpoint between $\mathrm{M}$ phace and citokynesis detecting if all choromosomes are attached to spindle.

Checking mechanisms include certain proteins and genes like p13, p16, p19, p21, and p53. 


\section{Chapter 3}

\section{MATHEMATICAL AND COMPUTATIONAL MODELING}

\subsection{Introduction (quantitative, qualitative, and stochastic approach)}

Biological systems have quantitative and qualitative characteristics. To model any kind of biological process we need first to sketch its qualitative model that will depict its structure. After that, we can add dynamical properties of the process by making quantitative model.

Our research is concerned with processes in systems biology meaning that we are modeling already existing entities.

systems biology: modelling as formal knowledge representation

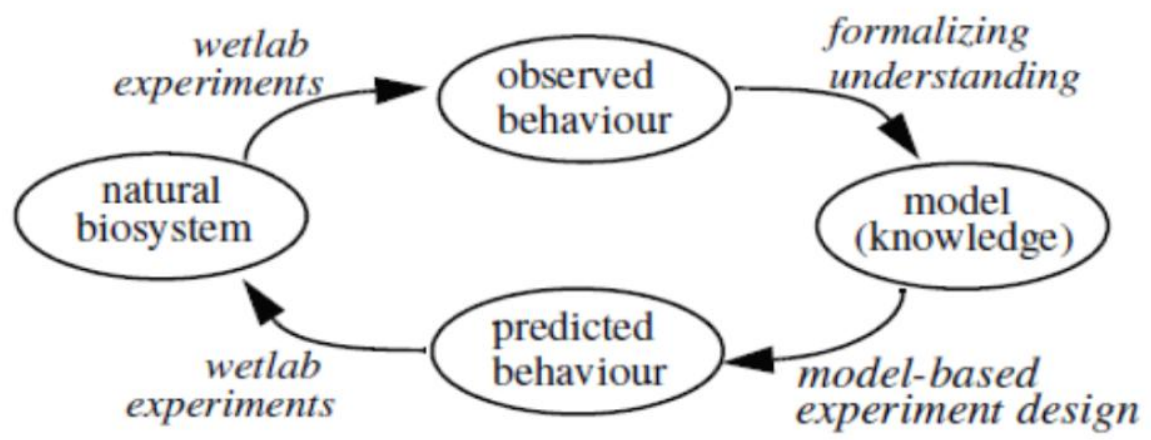

Figure 14. Systems biology - modeling as formal knowledge representation (taken from [7]) 
Our modeling is based on so-called wet lab results. So, we are modeling observed behaviour. Our model will help to predict behavior. Predicted behavior will give better insight for next selection of wet lab results.

First we start with qualitative model that does not depend on kinetic information but rather on the network topology and presence of spices. Since biological processes depend on time and concentration, after validating qualitative model, we move to stochastic approach by assigning scholastic rate function to all reaction in the network. However, to be able to use those results in future analysis we need some solid results so we will try to derive quantitative model by considering only deterministic rate functions. Rate functions basically define kinetics of reactions.

\subsection{Modeling with differential equations}

When we model biological system we are mainly interested in its dynamics apart from its structure. Biological processes basically are made of set of chemical reactions. We will try to define speed of those reactions as well as concentration of substrates and products involved in it.

Mathematical tool for calculating speed are derivatives. Therefore, we will use differential equations to calculate rate of change in chemical reactions that occur in biological processes. In our work that follows for each model we will provide differential equations that will define rate of change in reaction.

\subsection{Modeling with Petri nets}

Computational tool for modeling biological systems that we will use is called Petri nets. Reasons for choosing Petri nets are: 
- ability to model reactions involving real numbers (concentrations of substances are real numbers not just integers, speed of reactions is also represented using real numbers not just integers) and also

- ability to model concurrent processes (cell cycle involves different processes happening at the same time)

As mentioned before, starting point for modeling is creating structural model. For that we use ordinary Petri nets. After that, we need to make dynamic model that will incorporate kinetics of observed system. Stochastic and continuous Petri nets would do the job. Sometimes we will deal with hybrid Petri nets since some biological models are hybrid employing different structural processes. In our work we will be using software called CPN Tools.

\subsection{Law of mass action}

Law for Mass Action is one of basic laws of chemical kinetics and it states that "speed of chemical reaction depends on concentration of reactants presented in reactions or better say speed is proportional to concentration of reactants". Higher concentration of reactants means faster the speed of reaction. We also call speed rate of action of chemical reaction (reaction rate).

Generic chemical reaction that we are concerned with looks like:

$$
m A+n B \stackrel{k}{\longrightarrow} C \quad \text { (reaction } 1)
$$

where:

A,B,C - reactants; $\mathrm{m}, \mathrm{n}$ - stoichiometry coefficients; and $\mathrm{k}$ - reaction constant 
Speed or reaction rate of chemical reaction can be written as:

$$
r=k[A]^{m}[B]^{n} \quad \text { (equation 1) }
$$

$\mathrm{r}-$ reaction rate (speed or velocity of reaction)

Example for Law of Mass Action is given below:

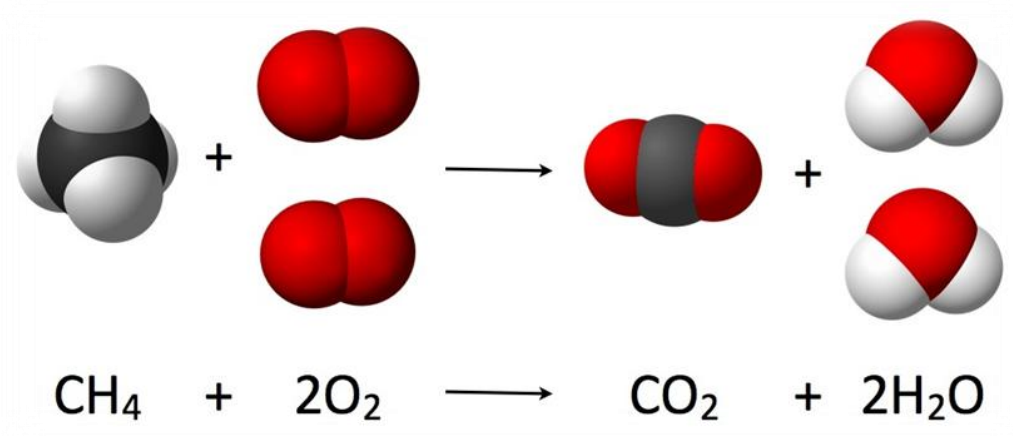

Figure 15. Compustion reaction of methane: methane +2 oxygen molecules $=$ carbon-dioxide +2 water molecules

This law is useful to obtain the correct equilibrium equation for a broad range of types of reactions. However, regarding studies of dynamics of reactions, these rate expressions are only applicable to elementary reactions.

\subsection{First - order or unimolecular reactions}

One of the simplest reactions for modeling is first-order reaction where we have one substrate and one product.

$$
A \stackrel{k}{\longrightarrow} B \quad \text { (reaction 2) }
$$

This reaction describes conversion of substrate $\mathrm{A}$ into product $\mathrm{B}$ at reaction rate $\mathrm{k}$. 
Ordinary differential equation giving concentrations of both A and B can be written as:

$$
\frac{d[A]}{d t}=-\frac{d[B]}{d t}=-k[A] \quad \text { (equation 2) }
$$

[ X ] represents concentration of substance $X$

Concentration represents the number of molecules in one liter of solution and is it measured in mole/liter. The reaction rate constant $\mathrm{k}$ can take up values from the order of fraction of a second up to several minutes depending on reaction type.

Petri net model of unimolecular reaction looks like as follows:

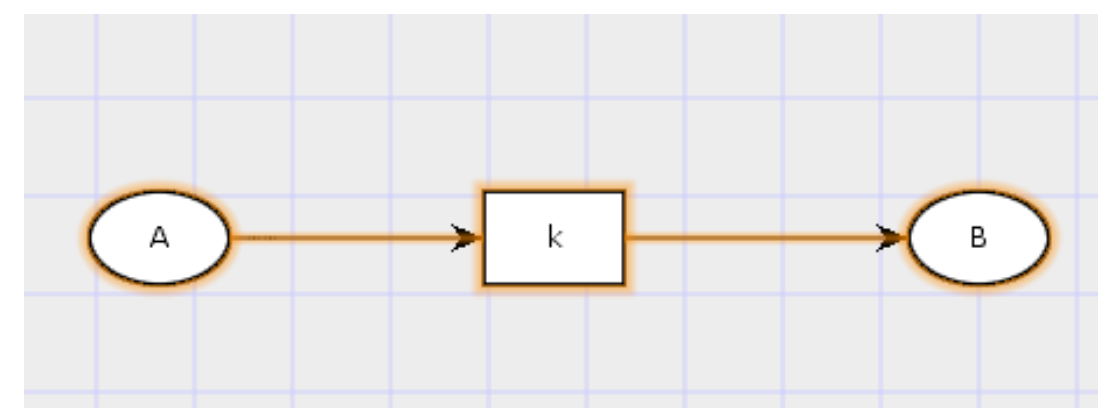

Figure 16. Petri net representation of unimolecular reaction

Example of unimolecular reaction is radioactive decay which happens due to unstable core of atomic nuclues of element or RNA folding process.

As stated before in Mass Action Law, rate of change (speed of reaction) is proportional to $[\mathrm{A}]$, concentration of $\mathrm{A}$. 


\subsection{Second - order or bimolecular reactions}

Next type of reaction that we are interested in are second - order or bimolecular reactions where we have two substrates converting to one product at reaction rate $\mathrm{k}$.

$$
A+B \stackrel{k}{\longrightarrow} C \quad \text { (reaction 3) }
$$

Ordinary differential equations depicting this type of reaction would be:

$$
\begin{gathered}
\frac{d[A]}{d t}=\frac{d[B]}{d t}=-k[A][B] \quad \text { (equation 3) and } \\
\frac{d[C]}{d t}=k[A][B] \quad \text { (equation 4) }
\end{gathered}
$$

Petri net model for bimolecular reaction is shown below:

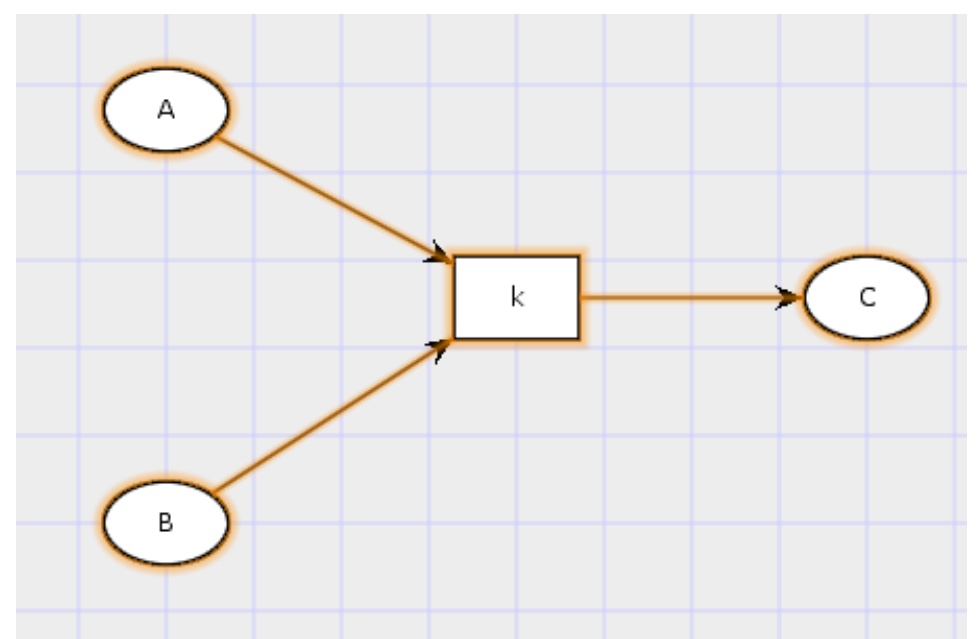

Figure 17. Petri net model of bimolecular reaction

Rate of change in bimolecular reaction is proportional to $[\mathrm{A}][\mathrm{B}]$, product of both concentrations A and B. 


\subsection{Reversible mass action or reversible reactions}

In general, all chemical reactions are reversible and current direction of reaction depends on thermodynamic conditions presented. Let's start with reversible unimolecular reaction.

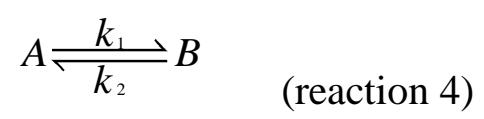

Given reversible reaction represents two reactions:

$$
\begin{array}{ll}
A \stackrel{k_{1}}{\longrightarrow} B \quad \text { (reaction 5) } \\
B \stackrel{k_{2}}{\longrightarrow} A \quad \text { (reaction 6) }
\end{array}
$$

where $\mathrm{A}, \mathrm{B}$ are reactants and $\mathrm{k}_{1}, \mathrm{k}_{2}$ are reaction rate constants.

Ordinary differential equation representing this process looks like:

$$
\frac{d[A]}{d t}=-\frac{d[B]}{d t}=-k_{1}[A]+k_{2}[B]
$$

(equation 5)

Petri net model of reversible unimolecular reaction is given below:

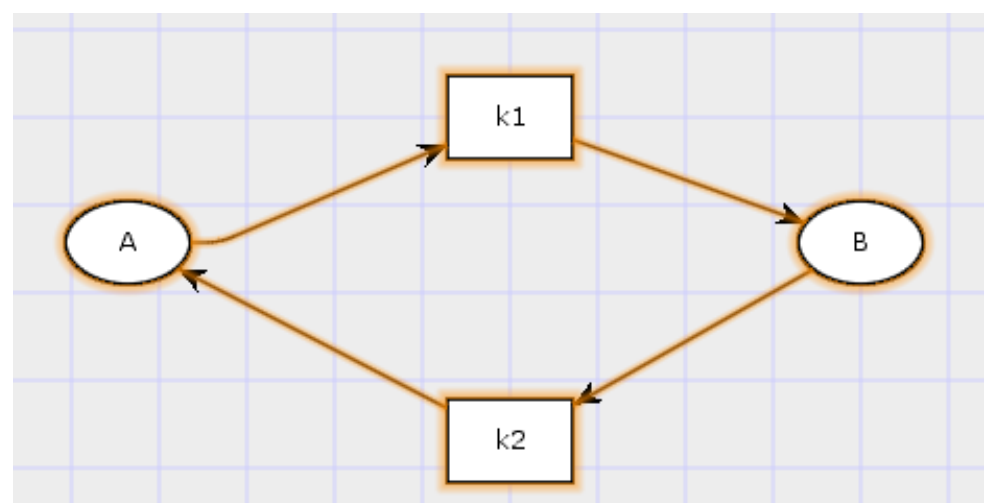

Figure 18. Petri net model of reversible unimolecular reaction 
Bimolecular reaction can be also reversible, same as unimolecular reaction.

$$
A+B \underset{k_{2}}{\stackrel{k_{1}}{\rightleftharpoons}} C
$$

(reaction 7)

Ordinary differential equations representing reversible case look like:

$$
\begin{gathered}
\frac{d[A]}{d t}=\frac{d[B]}{d t}=-k_{1}[A][B]+k_{2}[C] \\
-k_{1}[A][B]+k_{2}[C]=k_{1}[A][B]-k_{2}[C]
\end{gathered}
$$

Petri net model of second - order reaction is drawn on figure below:

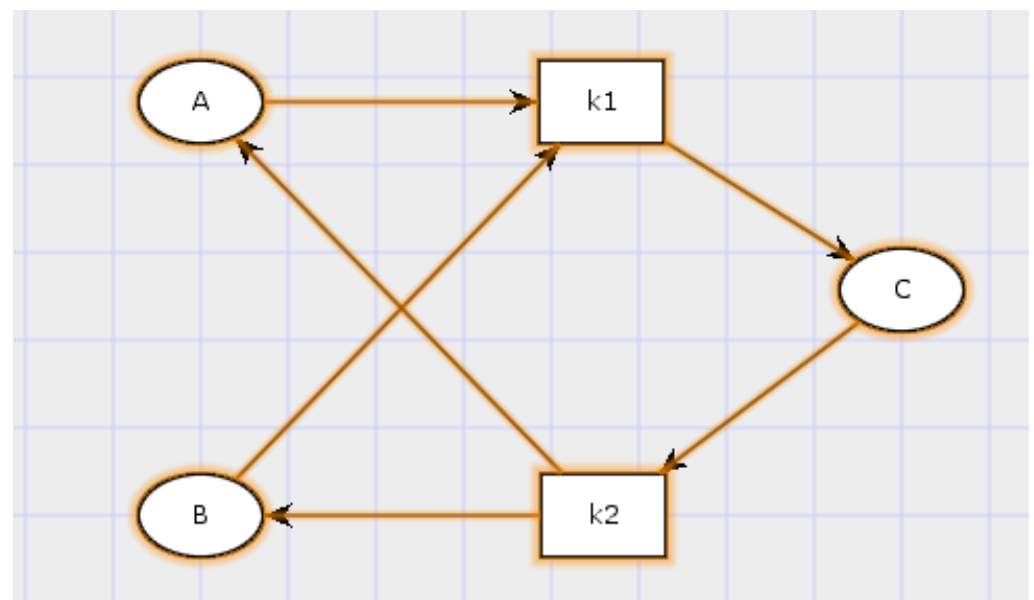

Figure 19. Petri net model of reversible bimolecular reaction

\subsection{Steady states}

There are processes that keep on going in continuous manner. In such processes concentrations of reactants remain unchanged in time regardless of thermodynamic properties. Flow of mass is constant in time inspite of ongoing process that is trying 
to change it. Mathematical statement depicting such environment requires partial derivatives with respect to time to be equal to zero.

$$
\frac{d[A]}{d t}=0 \quad \text { (equation 8) }
$$

Particular case of steady state is dynamic equilibrium. Dynamic equilibrium is achieved when in reversible reaction ratio of reactants ceases to change, even substances move at constant rate. In dynamic equilibrium there is no change in composition of mixtures. In case of dynamic equilibrium two or more processes occur at the same rate.

Differential equations describing steady state for bimolecular reaction are given below:

$$
\frac{d[A]}{d t}=\frac{d[B]}{d t}=\frac{d[C]}{d t}=0
$$

Substituting expressions from equations 6 and 7 into equation 9:

$$
-k_{1}[A][B]+k_{2}[C]=k_{1}[A][B]-k_{2}[C] \quad \text { (equation 10) }
$$

We introduce equilibrium constant $\mathrm{K}_{\text {equlibrium }}$ :

$$
K_{\text {equilibrium }}=\frac{k_{2}}{k_{1}}=\frac{[A][B]}{[C]}
$$

(equation 11)

Lotka - Volterra model

To describe steady state theory we will use Lotka - Volterra model or sometimes called predator-prey model. It describes process of achieving dynamic equilibrium 
between predator population that depends on reproduction and movement of prey population. There are certain preconditions that are assumed as:

- Prey will have its own food always

- Predator population depends completely on prey population

- Rate of change of populations is proportional to its size

- There is no change in environmental variables and genetic adaption for species

- Predator will never stop eating prey

Let's look at different scenarios that will enable us to model this system and write differential equations for it.

I. If we denote prey population as $\mathrm{A}$, in case that there is no predator population, it will keep on reproducing without control by exponential rate. We can denote that as:

$$
A \stackrel{k_{\mathrm{A}}}{\longrightarrow} A+A \quad \text { (reaction 8) }
$$

In real life there are limitations for this behavior such as space and food resources for prey, but since we have already assumed that those limitations are excluded, we will proceed without considering them.

II. Predator B needs to feed on the prey A for its own reproduction. Equation depicting that looks like:

$$
A+B \stackrel{k_{A B}}{\longrightarrow} B+B \quad \text { (reaction 9) }
$$


III. If there will be no prey, predator will die:

$$
\left.B \stackrel{k_{B}}{\longrightarrow} \quad \text { (reaction } 10\right)
$$

$\mathrm{k}_{\mathrm{A}}, \mathrm{k}_{\mathrm{AB}}, \mathrm{k}_{\mathrm{B}}$ are kinetic parameters describing interaction of two species and they are positive constants. If they are known, we can determine system of differential equations that will define growth rate of populations over the time:

$$
\frac{d[A]}{d t}=k_{A}[A]-k_{A B}[A][B]
$$

Prey population depends on its own growth minus rate at which predator eats it.

$$
\frac{d[B]}{d t}=k_{A B}[A][B]-k_{B}[B]
$$

Predator population change depends on quantity of prey that eats (more prey caught bigger predator population) minus natural death. Solution of this system would be deterministic and continuous implying those generations of populations, prey and predator, are continuously overlapping.

Now to get back to steady state analysis, trying to find equilibrium point, we will look for size of initial populations. As shown before, we do that by setting rate of change of concentration in given process to zero:

$$
\begin{gathered}
\frac{d[A]}{d t}=0 \quad ; \quad \frac{d[B]}{d t}=0 \\
k_{A}[A]-k_{A B}[A][B]=0 \Rightarrow[B]=\frac{k_{A}}{k_{A B}} \quad \text { (equation 8) } \\
k_{A B}[A][B]-k_{B}[B]=0 \Rightarrow[A]=\frac{k_{B}}{k_{A B}} \quad \text { (equation 14) }
\end{gathered}
$$


Concentrations of populations, near dynamic equilibrium point, depend solely on parameters defining growth rate of prey $\mathrm{k}_{\mathrm{A}}$, growth rate of predator $\mathrm{k}_{\mathrm{B}}$, and interaction rate between prey and predator $\mathrm{k}_{\mathrm{AB}}$.

It is important to mention that for a steady state to occur there must be no accumulation of mass of energy over the time period. Also, in stochastic systems probabilities that different states will repeat will stay constant.

\subsection{Stability analysis}

Predator - prey dynamic system has two steady states: trivial one when both populations are equal to zero and second one where concentrations of populations depend on parameters $\mathrm{k}_{\mathrm{A}}, \mathrm{k}_{\mathrm{AB}}, \mathrm{k}_{\mathrm{B}}$ as shown in equations above.

As in other dynamic systems, stability of steady states can be examined using Jacobian matrix:

$$
J([A],[B])=\left(\begin{array}{cc}
k_{A}-k_{A B}[B] & -k_{A B}[A] \\
k_{A B}[B] & k_{A B}[A]-k_{B}
\end{array}\right)
$$

Jacobian matrix defines linear mapping from $\mathrm{R}^{2} \rightarrow \mathrm{R}^{2}$ that is the best linear approximation of growth rate of populations near steady states (equilibrium points). Now, let's examine those approximations near both steady states.

\section{Trivial case}

If we consider trivial case when concentrations of populations are reaching zero values $([\mathrm{A}]=0$ and $[\mathrm{B}]=0)$, Jacobian matrix will look like: 


$$
J(0,0)=\left(\begin{array}{cc}
k_{A} & 0 \\
0 & -k_{B}
\end{array}\right)
$$

In theory of dynamic systems, the behavior of the system near stationary point is related to eigenvalues of its Jacobian matrix at that point. In our case, eigenvalues are

$$
\lambda_{1}=k_{A}, \lambda_{2}=-k_{B} \quad \text { (equation 17) }
$$

Rule says that if both eigenvalues have real negative parts, then the system is stable near equilibrium point. But if any eigenvalue has real positive part, the system will be unstable around examined point. And last case, if eigenvalues are mainly zero, Jacobian is not really helpful for examining stability of system at given point.

Let's look at our eigenvalues of Jacobian matrix for prey - predator system near equilibrium point $([\mathrm{A}]=0,[\mathrm{~B}]=0)$. Since $\mathrm{k}_{\mathrm{A}}$ and $\mathrm{k}_{\mathrm{B}}$ are always greater than zero, one of eigenvalues will have negative real part implying that the system is unstable around this equilibrium point. Interpretation of obtained result would be that scenario when both populations come to extinction is unlikely to happen.

\section{Nontrivial case, second steady state}

Second steady state occurs when concentrations of populations depends on parameters. When we substitute values for [A] and [B] from equations 14 and 15 into Jacobian matrix, it will be:

$$
J\left(\frac{k_{B}}{k_{A B}}, \frac{k_{A}}{k_{A B}}\right)=\left(\begin{array}{cc}
0 & -k_{B} \\
k_{A} & 0
\end{array}\right)
$$

Eigenvalues for this matrix are:

$$
\lambda_{1}=i \sqrt{k_{A} k_{B}} \text { and } \lambda_{2}=-i \sqrt{k_{A} k_{B}} \quad \text { (equation 18) }
$$


Since eigenvalues do not have real parts, it is not possible to make conclusions using linear analysis. Since eigenvalues are on imaginary axes, they imply there is flow. Imaginary eigenvalues in dynamic systems are associated with so-called Hopf bifurcation.

Hopf bifurcation can be described as the appearance or the disappearance of a periodic orbit through a local change in the stability properties of a steady point.

In our case it means that we will have neutrally stable steady state that will lead to limit cycles or closed orbits surrounding equilibrium point. Closed orbits correspond to continuous overlapping of populations of prey and predator where probabilities that different states will repeat stay constant.

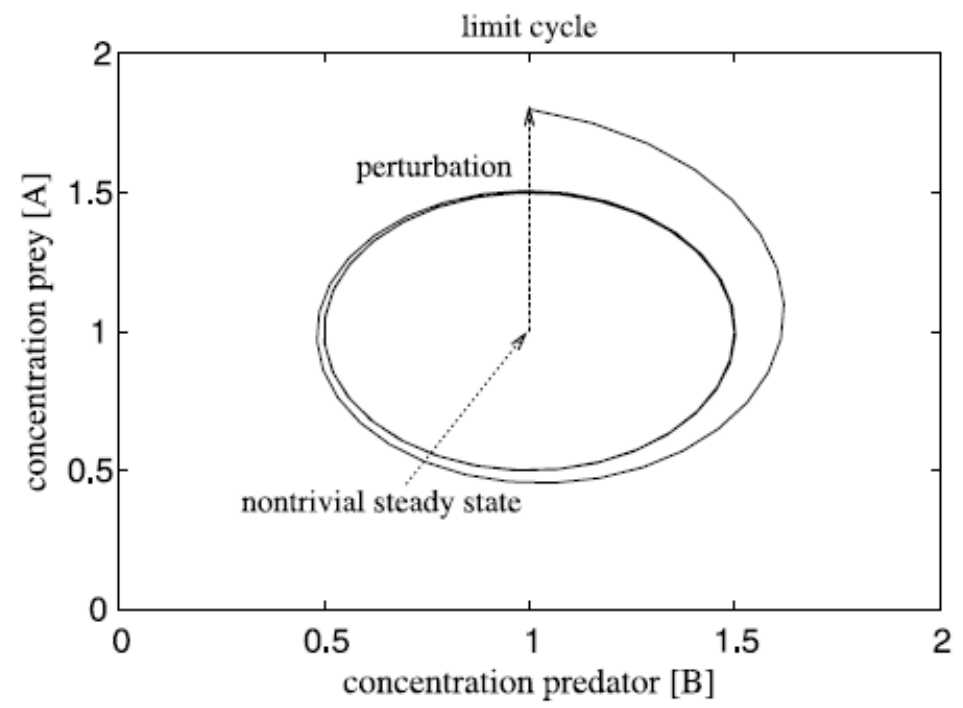

Figure 20. Sketch of a limit cycle in the phase plane of concentrations. The limit cycle emerges by a perturbation from the neutrally stable steady-state at $[\mathrm{A}]=[\mathrm{B}]=1$ and converges to a stable periodic orbit (taken from [8]) 


\subsection{Michaelis - Menten kinetics}

After describing some of quantitative properties of dynamic biological systems that include cell cycle process as well, we will get back to qualitative modeling of same. Until now we did not discuss how to model reactions that need extra help in order to speed up its occurrence. Such reactions, as mention before, need substances called enzymes. So, once again, let's give definition of enzymatic catalytic reaction. It is such reaction where the conversion of a substrate into a product is catalyzed by an enzyme.

First step in modeling enzymatic reactions is to find reaction constants and rates of change for those reactions that assume following things:

- The concentration of product is close to zero meaning that reaction is in starting mode

- Reaction is not reversible

- Concentration of substrate is much bigger than concentration of enzyme

Simple enzymatic reaction is given below:

$$
A+H \rightarrow B \quad(\text { reaction } 11)
$$

Where $\mathrm{A}$ is substrate, $\mathrm{H}$ is enzyme, and $\mathrm{B}$ is product of the reaction; and $[\mathrm{A}]>>[\mathrm{H}]$.

However, this type of enzymatic reaction is just starting point for modeling enzymatic reaction because it is not very common in reality. More common case is when both substrate and product have ability to bind to so-called binding site of 
enzyme and when reaction is reversible as well. We have already given example of such reaction before as translation of mRNA. General form of enzymatic reaction where Mass Action principle is preserved looks like:

$$
A+H \underset{k_{2}}{\stackrel{k_{1}}{\rightleftarrows}} A \mid H \stackrel{k_{3}}{\longrightarrow} B+H
$$

(reaction 12)

Petri net model of reaction 12 is given below:

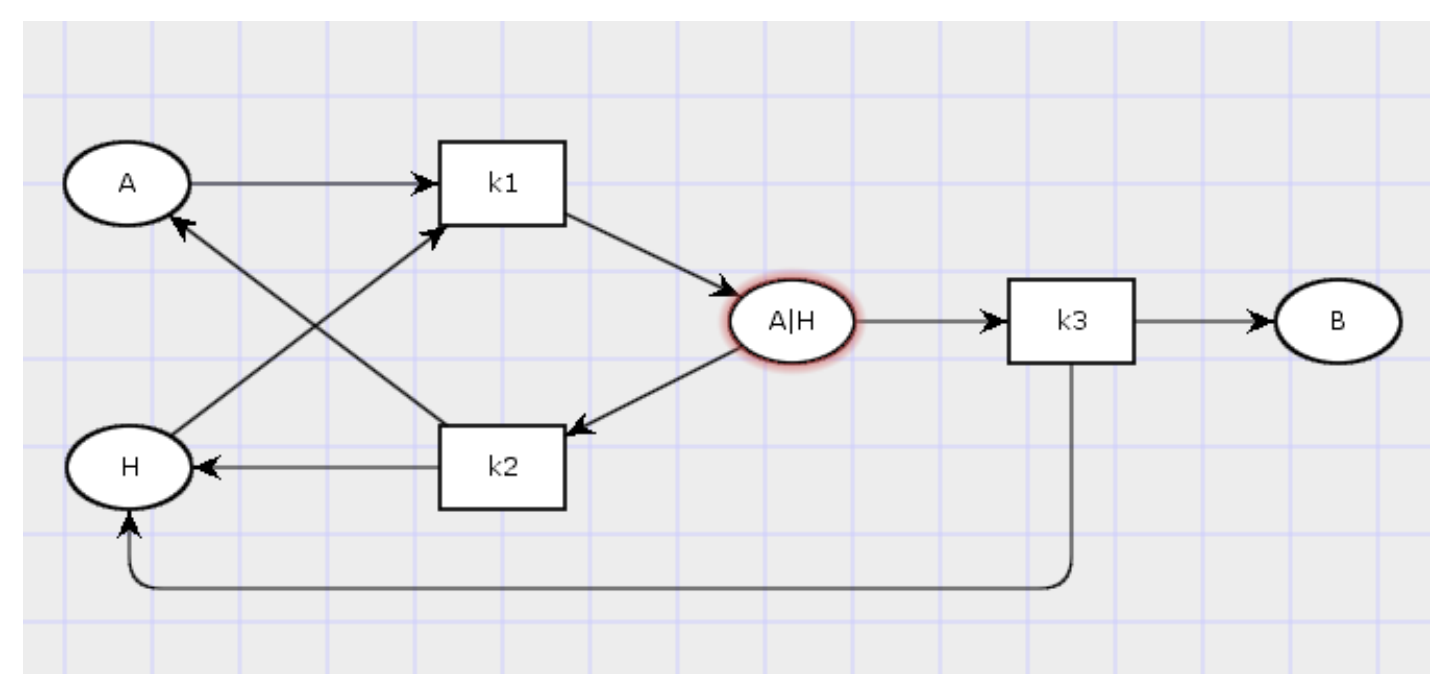

Figure 21. Petri net model of enzymatic reaction

Substrate A binds to binding site of enzyme $\mathrm{H}$ forming complex $\mathrm{A} \mid \mathrm{H}$. Enzyme changes substrate A to form product B and after that it leaves complex releasing product B. Rates of change of concentrations are given in form of differential equations:

$$
\begin{gathered}
\frac{d[A]}{d t}=-k_{1}[A][H]+k_{2}[A \mid H] \\
\frac{d[A \mid H]}{d t}=k_{1}[A][H]-k_{2}[A \mid H]-k_{3}[A \mid H]
\end{gathered}
$$




$$
\begin{gathered}
\frac{d[B]}{d t}=k_{3}[A \mid H] \\
\frac{d[H]}{d t}=-k_{1}[A][H]+k_{2}[A \mid H]+k_{3}[A \mid H]
\end{gathered}
$$

As we can see from equation 20 so-called catalytic rate $v=\frac{d[B]}{d t}$ depends directly on concentration of substrate-enzyme complex. Examining substrate-enzyme complex we can notice that concentration of this complex remains constant even if concentrations of substrate and product change. Described condition is called quasisteady-state assumption (QSSA). Constant concentration means that rate of change of that concentration is equal to zero as written below:

$$
\begin{gathered}
\frac{d[A \mid H]}{d t}=0 \\
k_{1}[A][H]-k_{2}[A \mid H]-k_{3}[A \mid H]=0 \\
{[A \mid H]=\frac{k_{1}}{k_{2}+k_{3}}[A][H] \quad \text { (equation 23) }}
\end{gathered}
$$

As we can see from equation 24 there is parameter that measure substrate - enzyme interaction called Michaelis - Menten constant. It is defined as follows:

$$
\frac{[A][H]}{[A \mid H]}=\frac{k_{2}+k_{3}}{k_{1}}=M_{\text {const }}
$$

(equation 25)

$\mathrm{M}_{\text {const }}$ represents concentration of substrate when reaction rate reaches half of its maximum value or better to say half of active sites of enzyme are filled. 
Now we need to proceed with further calculations in order to find catalytic rate v.

Using Mass Action law we can state that total concentration of enzyme is equal to concentration of free enzyme plus concentration of substrate - enzyme. It is constant since enzyme does not change its structure:

$$
[H]+[A \mid H]=[H]_{0} \quad \text { (equation 26) }
$$

$[\mathrm{H}]_{0}$ is total concentration of enzyme.

Now, if we substitute value for $[\mathrm{H}]$ from equation 26 into equation 24 :

$$
\begin{gathered}
{[A \mid H]=\frac{k_{1}}{k_{2}+k_{3}}[A][H]=\frac{[A][H]}{M_{\text {const }}}=\frac{[A]\left([H]_{0}-[A \mid H]\right)}{M_{\text {const }}}} \\
{[A \mid H]=\frac{[A][H]_{0}}{M_{\text {const }}+[A]} \quad \text { (equation 27) }}
\end{gathered}
$$

We have calculated concentration of substrate - enzyme complex when it is under QSSA, so we can proceed with finding catalytic rate of reaction. When concentration of substrate is excessively given, meaning $[\mathrm{A}] \gg \mathrm{M}_{\text {const }}$, rate of reaction reaches its maximum and we denote that as:

$$
V_{\max }=k_{3} *[H]_{0} \quad \text { (equation 28) }
$$

From this equation

$$
k_{3}=\frac{V_{\max }}{[H]_{0}}
$$

(equation 29) 
Finally we can find rate of reaction $\mathrm{v}$ by substituting equations 24 and 29 into equation 21 as follows:

$$
\begin{gathered}
v=\frac{d[B]}{d t}=k_{3}[A \mid H]=\frac{V_{\max }}{[H]_{0}} * \frac{[A][H]_{0}}{M_{\text {const }}+[A]}=V_{\text {max }} * \frac{[A]}{M_{\text {const }}+[A]} \\
v=\frac{d[B]}{d t}=V_{\text {max }} * \frac{[A]}{M_{\text {const }}+[A]} \quad \text { (equation 30) }
\end{gathered}
$$

Speed of consuming substrate and producing product depends on concentration of substrate. Higher concentration of substrate will mean faster reaction rate.

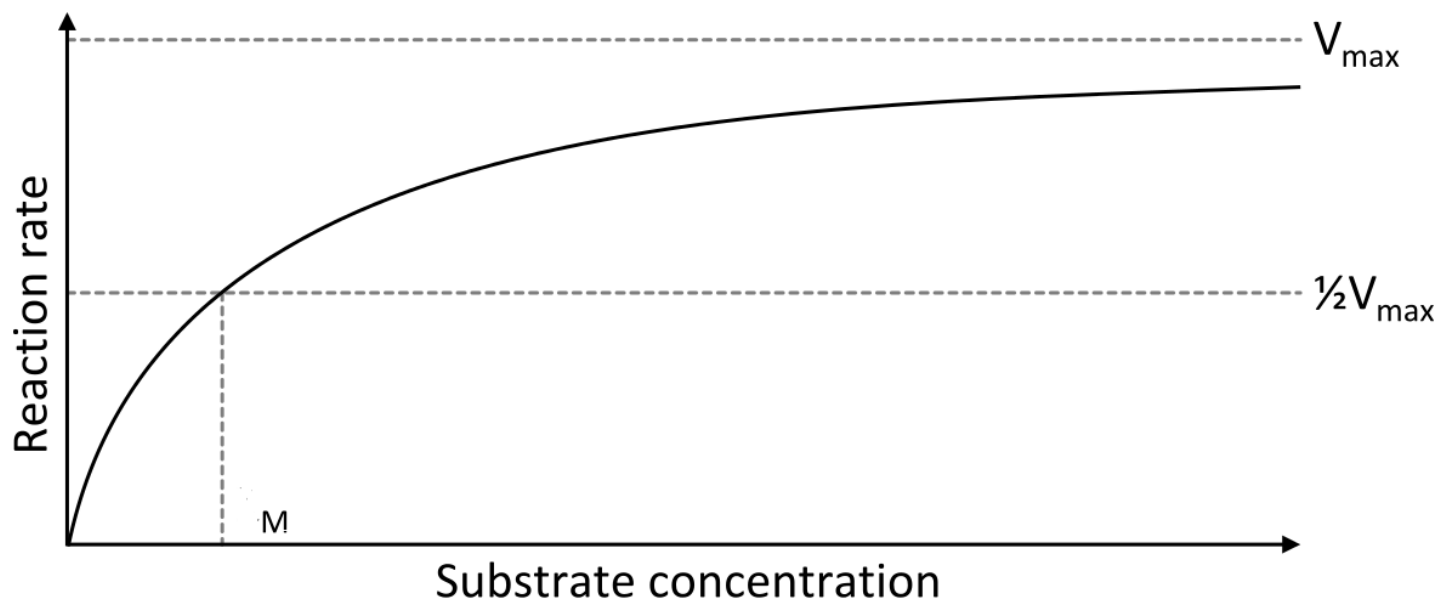

Figure 22. Saturation curve for enzyme reaction (taken from [9])

High affinity of substrate for enzyme means small value of Michaelis - Menten constant meaning rate of reaction will approach its peak fast. Michaelis - Menten constant however depends on concentration of substrate and enzyme as well as on external environmental conditions like temperature and ph value. 


\subsection{Enzyme kinetics with inhibitors}

Sometimes there is need to slow down enzymatic reaction. It is done using substances called inhibitors that usually have similar structure as substrates. Substrate forms substrate - enzyme complex by binding with enzyme at so-called active site. It is shown on picture below:
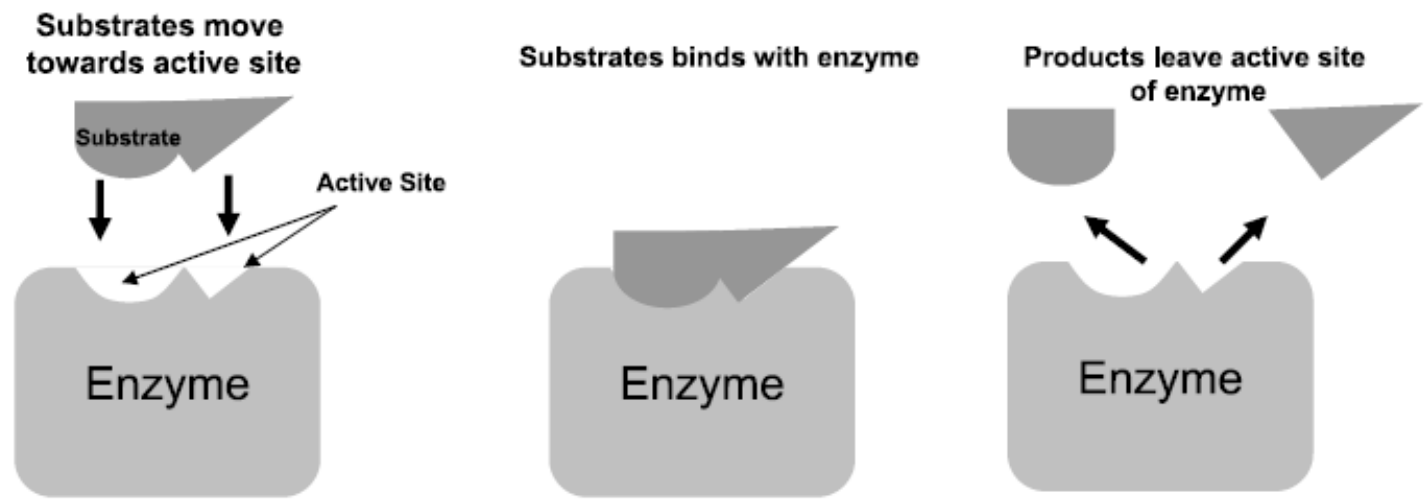

Figure 23. Basic working process of enzyme (taken from [8])

There are three types of enzymatic reactions with inhibitors:

- Competitive

- Noncompetitive

- Uncompetitive

\subsubsection{Enzyme kinetics with competitive inhibition}

Competitive inhibition occurs when substrate and inhibitor bind to same active site on enzyme so they start competing for it. Effect of inhibition depends on concentrations of inhibitor and substrate. In competitive inhibition enzyme can bind just to one of them: inhibitor or substrate. It cannot bind to both of them at the same time. Reactions describing this kind of inhibition are given below: 


$$
\begin{aligned}
& H+I \rightarrow H \mid I \\
& H+A \rightarrow A \mid H \quad \text { (reaction 13) }
\end{aligned}
$$

$\mathrm{H}$ is notation for enzyme, $\mathrm{I}$ is notation for inhibitor, and $\mathrm{A}$ is notation for substrate.

Petri net representation of given system would be:

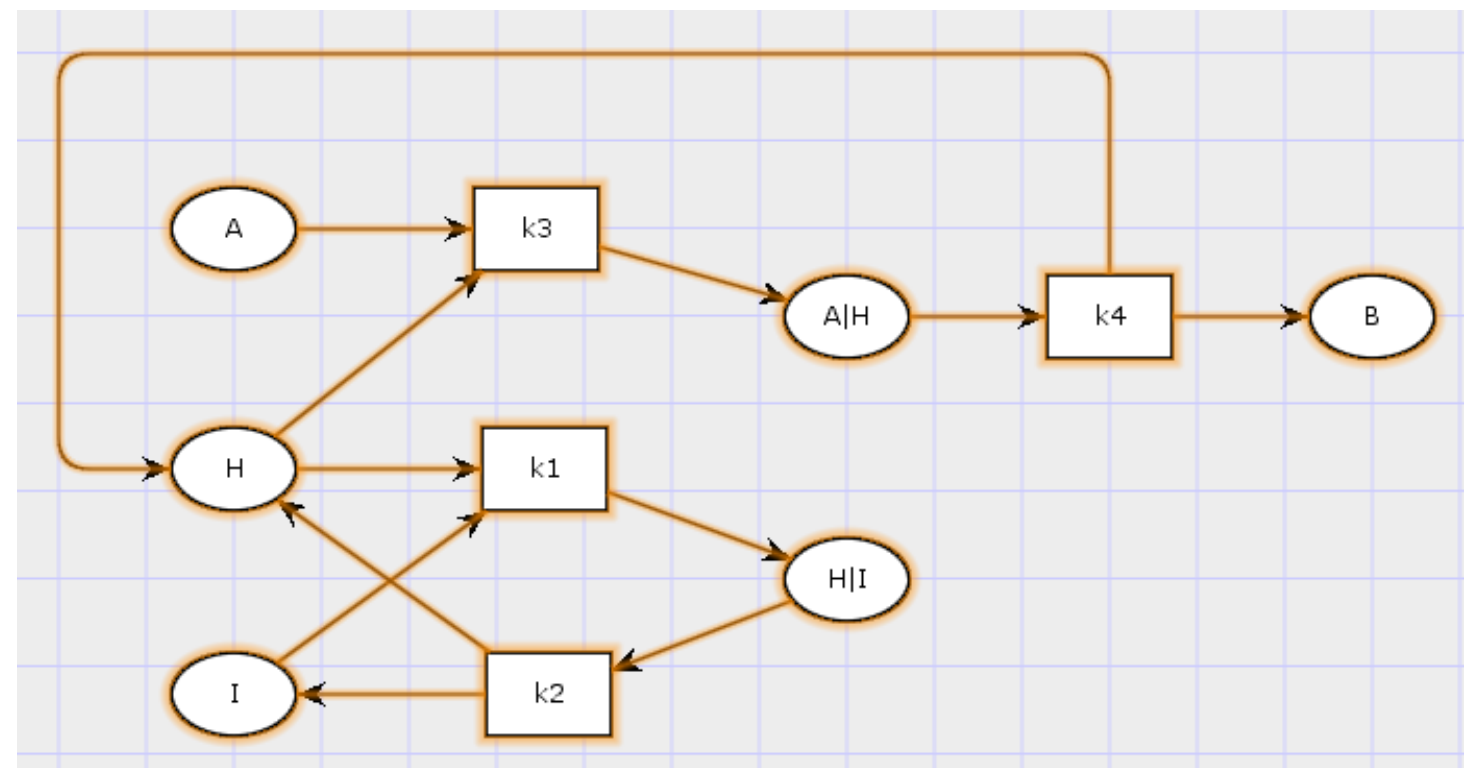

Figure 24. Petri net representation for competitive inhibition

If inhibitor binds with enzyme than, applying QSSA, constant $M_{I}$ will depict equilibrium concentrations for reverse binding of inhibitor to enzyme:

$$
M_{I}=\frac{[I][H]}{[H \mid I]}
$$

(equation 31)

$\mathrm{H} \mid \mathrm{I}$ is not active. Total concentration of enzyme equals so concentration of free enzyme plus concentration of enzyme - inhibitor complex plus concentration of substrate - enzyme complex:

$$
[H]_{0}=[H]+[H \mid I]+[A \mid H]
$$

(equation 32) 
Taking into account all this plus concentration of substrate - enzyme complex, rate of reaction will be:

$$
v=V_{\max } * \frac{[A]}{\alpha M_{\text {const }}+[A]}
$$

(equation 33)

where $\quad \alpha=1+\frac{[I]}{M_{I}}$

\subsubsection{Enzyme kinetics with uncompetitive inhibition}

Uncompetitive inhibition occurs after enzyme has bind to substrate. In this type of inhibition substrate and inhibitor do not compete for binding to same active site. First substrate binds to its active site and after that inhibitor binds to substrate - enzyme complex to its regulatory binding site. Reaction describing uncompetitive inhibition is given below:

$$
A+H \rightarrow A|H+I \rightarrow A| H \mid I \quad \text { (reaction 14) }
$$

Petri net model of uncompetitive inhibition given in reaction above looks like:

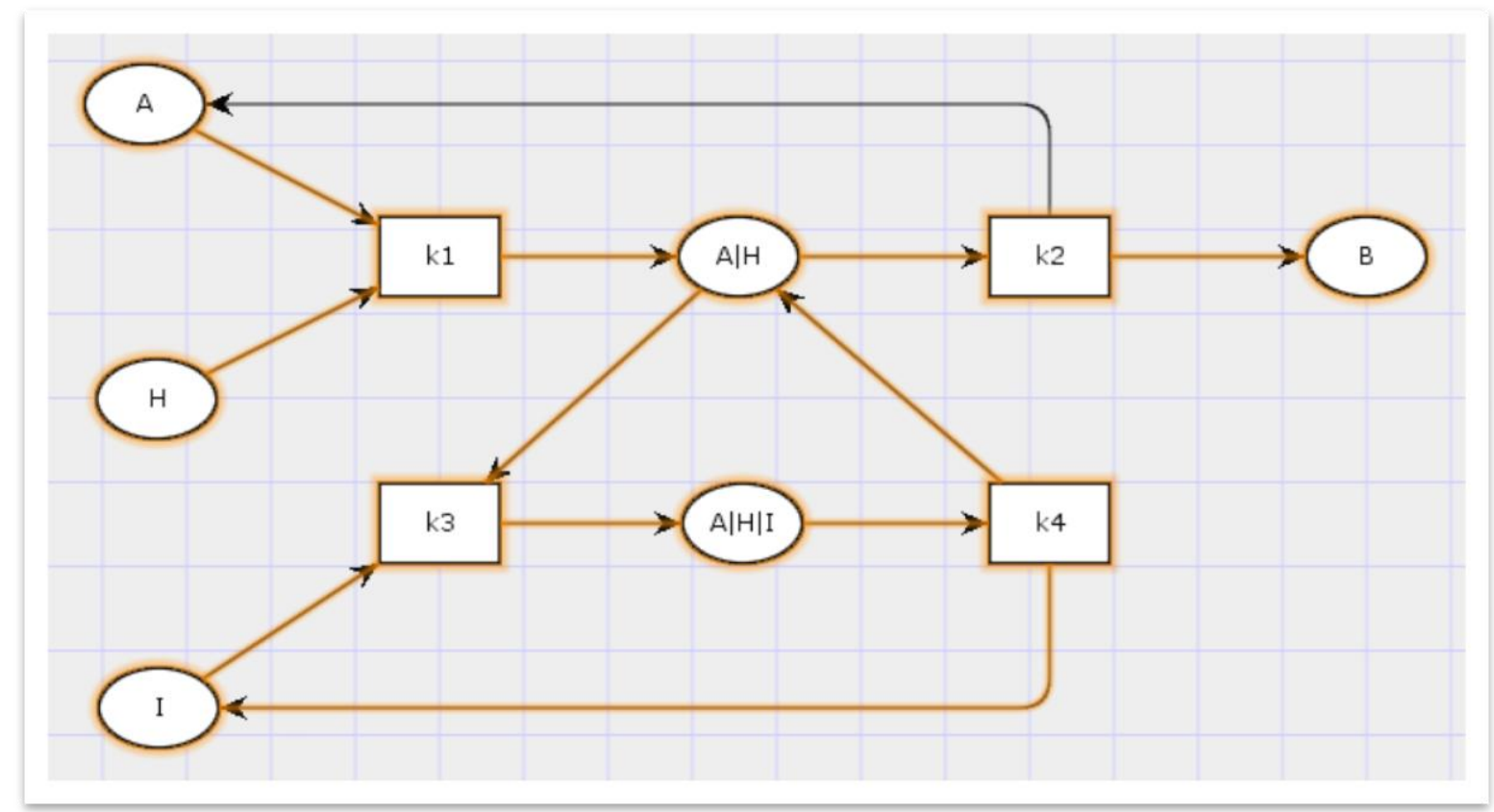

Figure 25 Petri net representation of uncompetitive inhibition 
Substrate - enzyme - inhibitor complex is not active catalytically. Enzyme inhibitor complex will not be formed. When we apply QSSA, constant depicting $\mathrm{A}|\mathrm{H}| \mathrm{I}$ binding will look like:

$$
M_{A H I}=\frac{[A \mid H][I]}{[A|H| I]} \quad \text { (equation 34) }
$$

Rate of this type of reaction, taking into account $\mathrm{M}_{\mathrm{AHI}}$, can be calculated using following formula:

$$
v=V_{\max } * \frac{[A]}{M_{\text {const }}+\alpha_{A H I}[A]}
$$

where $\alpha_{A H I}=1+\frac{[I]}{M_{A H I}}$

\subsubsection{Enzyme kinetics with noncompetitive inhibition}

Until now we dealt with enzymatic reactions in which inhibitor was successful in stopping catalytic activity. There is third type of reactions in which inhibitor is successful only in slowing down enzyme's activity; it will not inactivate catalytic reaction. Such type of reactions is called noncompetitive inhibition. Noncompetitive inhibition requires different binding site for inhibitor and substrate. Inhibitor binds to enzyme at so-called allosteric site. Inhibitor changes structure of enzyme resulting in fact that substrate can no longer bind as assumed to enzyme. In this way enzymatic activity is reduced. Figure below illustrates that: 


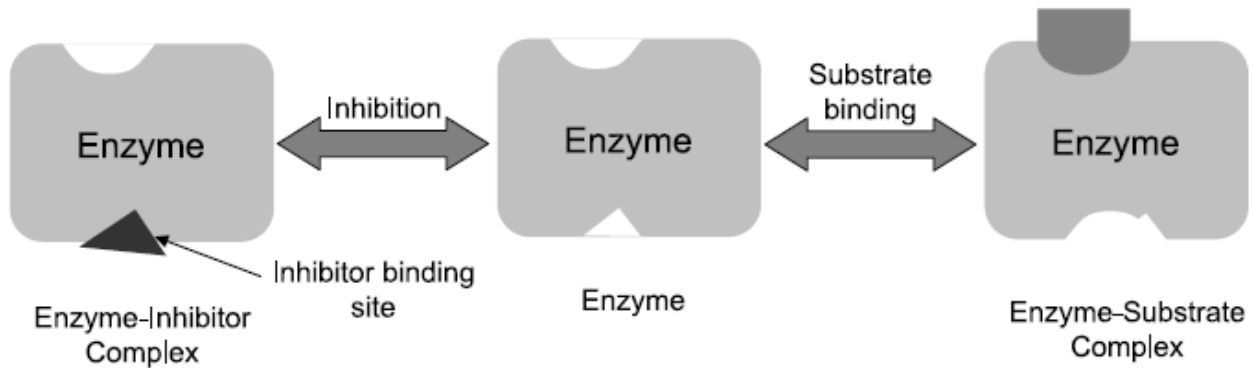

Figure 26. Noncompetitive inhibition

Reactions describing mentioned state are given below (reaction 15):

$$
\begin{array}{cc}
\mathrm{H}+\mathrm{A} \rightarrow & \mathrm{A} \mid \mathrm{H} \rightarrow \mathrm{B}+\mathrm{H} \\
+ & + \\
\mathrm{I} & \mathrm{I} \\
\uparrow & \uparrow \\
\mathrm{H} \mid \mathrm{I} & \mathrm{A}|\mathrm{H}| \mathrm{I}
\end{array}
$$

Petri net model of enzymatic allosteric reaction can be drawn as follows:

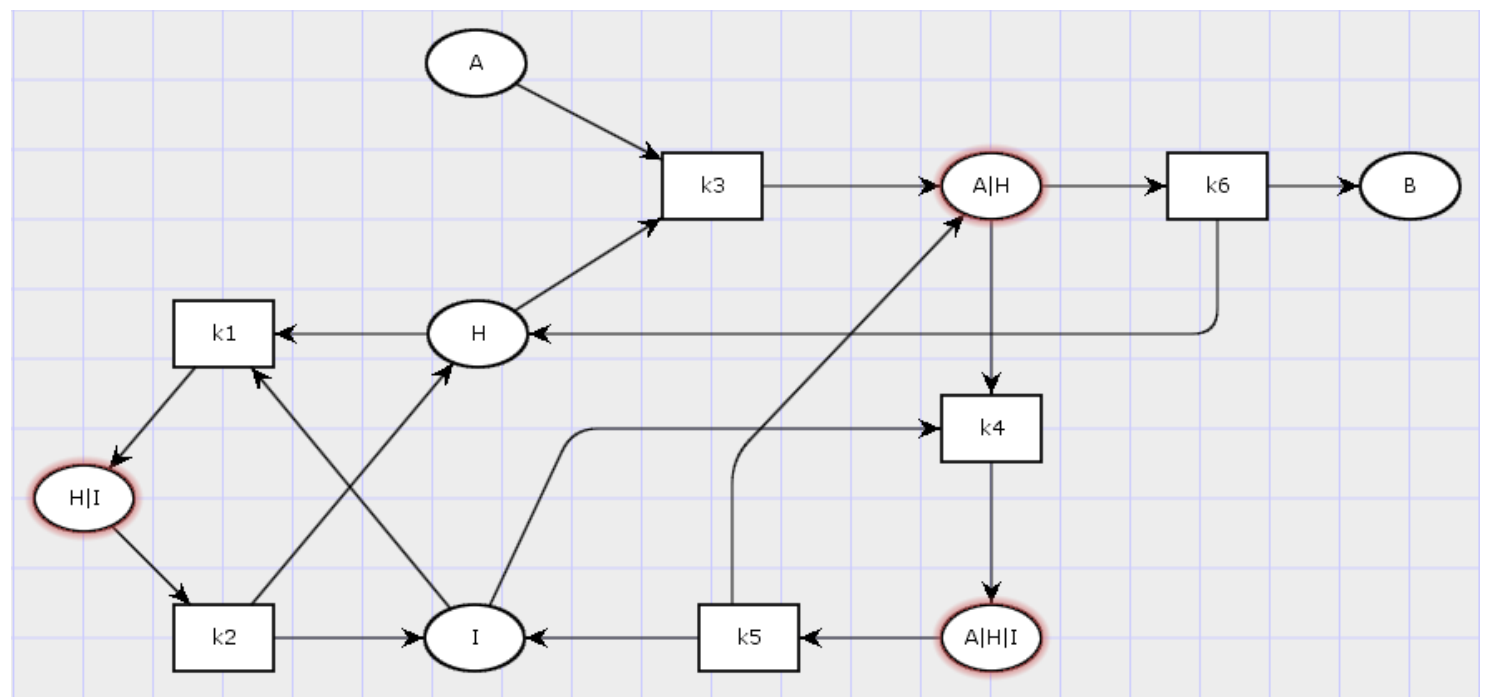

Figure 27. Petri net representation of noncompetitive inhibition 
To find rate of enzymatic allosteric reaction we will assume that both complexes (enzyme - inhibitor and substrate - enzyme - inhibitor) are in quasi - steady - state. If we take into account both constant $\mathrm{M}_{\mathrm{I}}$ and $\mathrm{M}_{\mathrm{AHI}}$, reaction rate will be:

$$
v=V_{\max } * \frac{[A]}{\alpha M_{\text {const }}+\alpha_{A H I}[A]} \quad \text { (equation 36) }
$$




\section{Chapter 4}

\section{CONCLUSION}

We have showed that biological processes, in particular cell cycle, can be modeled using differential equations and Petri nets. As those processes are basically made of set of chemical reactions, our main concern was defining rate of change of those reactions. We have showed that reaction rates depend on concentration of substances involved as well as certain constants as in example of Michaelis - Menten kinetics. Mathematically, to model reactions meant to find change in concentrations for each substance involved in reaction (substrate, enzyme, inhibitor, and product). Reactions are governed by Mass Action law that assumes proportionality between speed of reaction and amount of concentration of substances involved. Computationally, to model reactions meant to define Petri net model for every considered reaction. In our research we were in particular interested in steady - states, including dynamic equilibrium, which led us to Lotka - Voltera model of prey - predator interactions. We came to conclusion that there are two steady - states: one when concentrations of both prey and predator are equal to zero which is trivial case, and second one when concentrations depend on kinetic parameters (nontrivial case). Trivial case gave us unstable equilibrium point. Nontrivial case provided us with stable equilibrium point. Analysis has been done using 
eigenvalues obtained from Jacobian matrices of steady - state systems. Next concern was reactions that are speeded up by another substance called enzymes. There we discussed Michaelis - Menten kinetics and how to obtain Michaelis - Menten constant that is one of parameters in finding speed of reactions. We found out that speed of enzymatic reactions as well as maximum speed of same is proportional to concentration of substrate. Bigger concentration of substrate means faster enzymatic reaction. Finally, we took look at inhibitor affected enzymatic reaction that can stop catalytic activity of reaction. It is possible to model biological processes (cell cycle included) using mathematical and computational tools to very detailed extend. In end, we can just mention that we used CPN Tools as software for modeling Petri net models of biological processes. 


\section{REFERENCES}

[1] Handbook Help Me Understand Genetics. (2015). Lister Hill National Center for Biomedical Communications, U.S. National Library of Medicine, National Institutes of Health, Department of Health \& Human Services.

[2] https://en.wikipedia.org/wiki/Prokaryote (August 2015)

[3] Michael Cummings. (2011). Human Heredity: Principles and Issues $9^{\text {th }}$ edition. Brooks/Cole.

[4] https://public.ornl.gov/site/gallery/default.cfm (August 2015)

[5] Bruce Alberts, Dennis Bray, and all. (2008). Essential Cell Biology, $3^{\text {rd }}$ edition. Garland Science, 2008.

[6] https://en.wikipedia.org/wiki/Signal_transduction (August 2015)

[7] Heiner, M., Gilbert, D., \& Donaldson, R. (2008). Petri Nets for Systems and Synthetic Biology. Lecture Notes in Computer Science 5016, 215-264.

[8] Koch, I., Reisig, W., \& Schreiber, F. (2011). Modeling in Systems Biology: The Petri Net Approach. Springer. 
[9] https://en.wikipedia.org/wiki/Michaelis\%E2\%80\%93Menten_kinetics (August 2015) 